Portland State University

PDXScholar

Restriction mapping and expression of recombinant plasmids containing the arsenic resistance genes of the plasmid R45

Terry M. Coons

Portland State University

Follow this and additional works at: https://pdxscholar.library.pdx.edu/open_access_etds

Part of the Genetics and Genomics Commons, and the Microbiology Commons Let us know how access to this document benefits you.

Recommended Citation

Coons, Terry M., "Restriction mapping and expression of recombinant plasmids containing the arsenic resistance genes of the plasmid R45" (1986). Dissertations and Theses. Paper 3597.

https://doi.org/10.15760/etd.5481

This Thesis is brought to you for free and open access. It has been accepted for inclusion in Dissertations and Theses by an authorized administrator of PDXScholar. Please contact us if we can make this document more accessible: pdxscholar@pdx.edu. 
AN ABSTRACT OF THE THESIS OF Terry M. Coons for the Master of science in Biology presented July 29, 1986.

Title: Restriction Mapping and Expression of Recombinant Plasmids Containing the Arsenic Resistance Genes of the Plasmid R45.

APPROVED BY MEMBERS OF THE THESIS COMMITTEE :
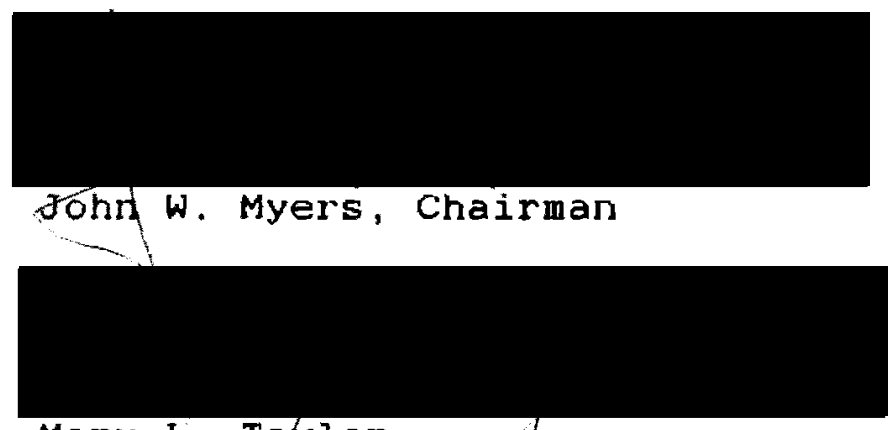

Mary L. Táylor

0

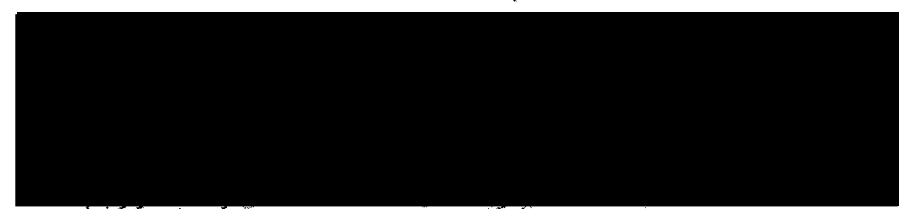

Deborah A. Duffigla
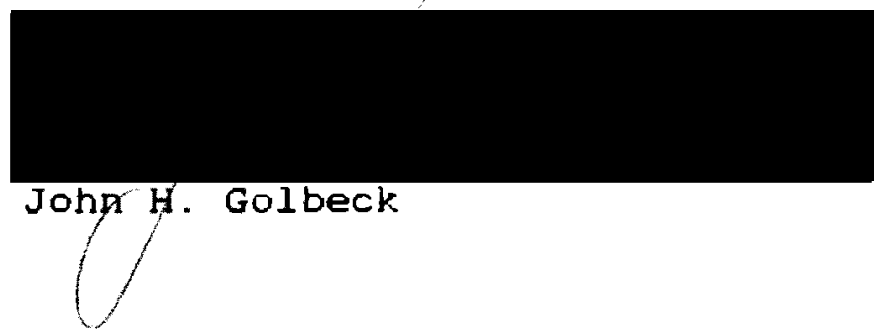

The trivalent (arsenite) and pentavalent (arsenate)

forms of arsenic are introduced into the environment

through the use of arsenic in herbicides, pesticides, 
fertilizers, and the smelting of arsenic-bearing ores. Bacteria resistant to arsenic are readily isolated from surface waters, sewage, and clinical infections. Although some bacterial resistance is provided by inducible phosphate transport systems that discriminate against arsenate, marked resistance is carried on bacterial plasmids.

A 6.9 kilobase fragment previously derived from one such plasmid, R45, and containing the genes for inducible resistance to arsenite and arsenate was ligated into the cloning vectors pUCB and pUC9 in opposite orientations and transformed into Escherichia coli JM 105. Insertion into the multiple cloning site of the pUc vectors places the inserted fragment under the inducible control of the lac operon promoter. An attempt was made to determine the direction of transcription in the fragment by growth in 10-oM isopropyl- $\beta$-D-thiogalactoside prior to challenge with arsenite.

The minimal inhibitory concentrations of arsenite for strains with and without recombinant plasmids were determined. Recombinant plasmids conferred up to five-fold greater resistance to arsenite than was observed in strains containing intact pUC vectors or no plasmid at all.

A restriction map of the fragment was constructed.

The fragment contained six restriction sites for the enzymes Pvu I, Bgl II, Sph I and Sal I. 
The recombinant plasmids were transformed into the maxicell strain E. coli CSR 603 to facilitate identification of the polypeptides encoded by the cloned fragment. Polypeptides of apparent molecular weights 62 , 16.5 and $13.5 \mathrm{kilodaltons}$ were identified. 
TO THE OFFICE OF GRADUATE STUDIES AND RESEARCH:

The members of the Committee approve the thesis of

Terry M. Coons presented July 29, 1986.
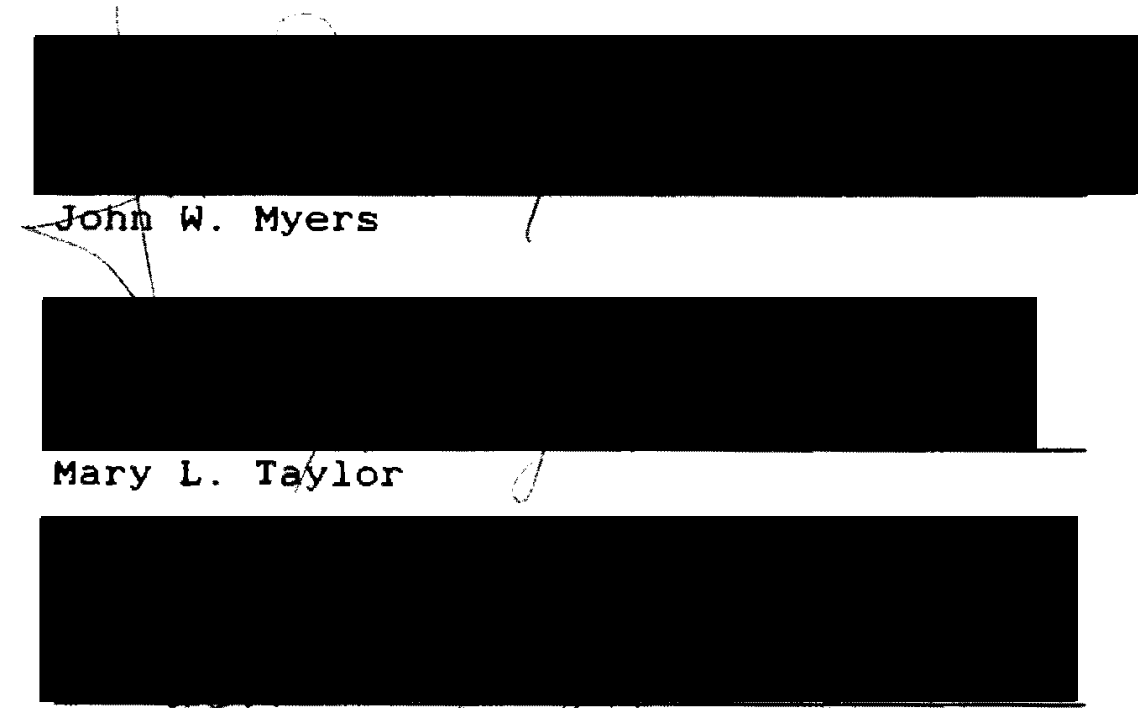

Deborah A. Duffield/7/

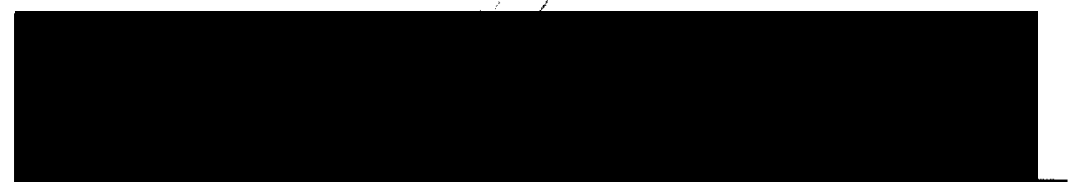

John/ H. Golbeck

AFPKOVED :
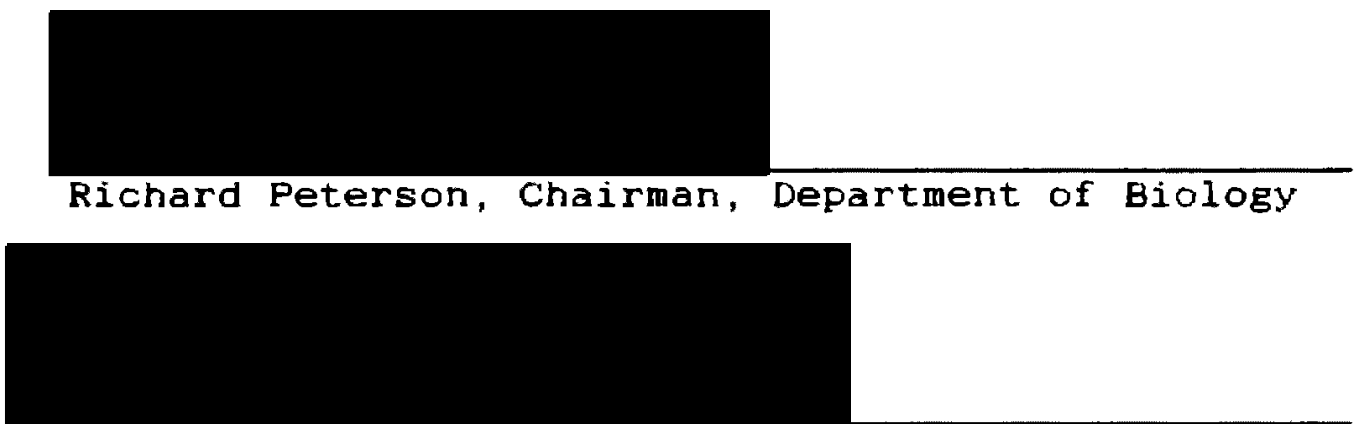

Bernard Ross, Dean of Graduate Studies and Research 


\title{
RESTRICTION MAPPING AND EXPRESSION \\ of RECOMBINANT PLASMIDS CONTAINING \\ THE ARSENIC RESISTANCE GENES \\ OF THE PLASMID R45
}

by

TERRY M. COONS

A thesis submitted in partial fulfillment of the requirements for the degree of

\author{
MASTER OF SCIENCE \\ in \\ BIOLOGY
}

Portland State University

1986 


\section{ACKNOWLEDGMENTS}

This thesis is dedicated to Jack Myers, my advisor and friend. Special thanks to Kathleen Sampson for sharing her knowledge and material support, and to Bonnie R. Lee, for her dedication and production skills. 
TABLE OF CONTENTS

PAGE

ACKNOWLEDGEMENTS $\ldots \ldots \ldots \ldots \ldots \ldots \ldots$ ii

LIST OF TAELES $\ldots \ldots \ldots \ldots \ldots \ldots \ldots \ldots \ldots$ vi

LIST OF FIGURES $\ldots \ldots \ldots \ldots \ldots \ldots \ldots \ldots$ vii

INTRODUCTION $\quad \ldots \ldots \ldots \ldots \ldots \ldots \ldots \ldots \ldots \ldots$

MATERIALS AND METHODS $\ldots \ldots \ldots \ldots \ldots \ldots \ldots .9$

Bacterial Strains and Sources........ 9

Growth Media.................. 11

Isolation of Plasmid DNA.......... 12

Isolation of Bacteriophage $\lambda$ DNA..... 13

Digestion of DNA with Restriction Endonucleases.................. 15

Electrophoresis of DNA Fragments...... 16

Isolation of DNA Fragments......... 16

Construction of Recombinant Flasmids... 17

Transformation.............. 18

Minimal Inhibitory Concentration

of Arsenite................... 20

Induction of Arsenite Resistance by

IPTG................... 20

Restriction Mapping of the Arsenite

Resistance Fragment.............. 21

Identification of Plasmid-Determined

Proteins.................... 
PAGE

RESULTS $\quad \ldots \ldots \ldots \ldots \ldots \ldots \ldots \ldots \ldots \ldots \ldots \ldots \ldots \ldots \ldots \ldots \ldots$

28

Isolation and Ligation of Arsenic

Resistant Fragment DNA............. 28

Transformation of Recombinant Plasmids. 28

Confirmation of Recombinant Plasmids... 29

Restriction Map................ 36

Minimal Inhibitory Concentrations...... 41

Arsenite Resistance Induction Assays... 41

Identification of Plasmid-Encoded

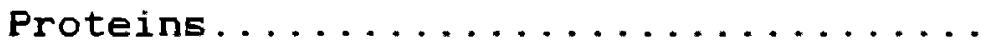

DISCUSSION .....................

LIST OF REFERENCES. ................... 60 


\section{LIST OF TABLES}

TABLE

PAGE

I. List of Abbreviations..........

10

II. Minimal Inhibitory Concentration

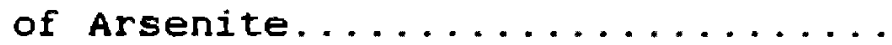




\section{LIST OF FIGURES}

1. Electrophoretic Analysis of Restriction Digests of Recombinant Plasmids......

2. Opposite Orientation of Insertions in Recombinant Plasmids............

3. Pyu I Restriction Map of Recombinant Plasmids.

4. Double Digests of the 845 Fragment...

5. Single Digests and Restriction Map of the R45 Fragment..............

6. Optimal Arsenite Concentration for Induction of Resistance............

7. Induction of Arsenite Resistance

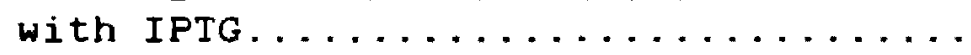

8. Plasmid-Determined Proteins..........

9. $\quad$-Lactamase and $36 \mathrm{Kdal}$ Protein...... 


\section{INTRODUCTION}

Elemental arsenic is found in the earth's crust, and oxides of arsenic are produced as by-products from the smelting of ores and the burning of fossil fuels in power plants (7). Arsenic is also added to the environment as an ingredient of many insecticides, herbicides and phosphate fertilizers (36). Practices causing increased erosion, as well as the use of arsenic in sheep dips to control ticks and fleas, also contribute to the incidence of arsenic in the environment. Major hazards to public health arise from local contamination of drinking water in areas surrounding mining or agricultural operations or from job-related inhalation of particles (7). In one study, $7 \%$ of 1500 freshwater samples exceeded the limit for arsenic recommended by the U.S. Public Health Service (7).

The two most common forms of inorganic arsenic are the pentavalent arsenate and the trivalent arsenite salts. Their mechanisms of toxicity differ. Arsenate toxicity arises from its similarity to phosphate both in geometry and reactivity (20). Arsenate can substitute for phosphate in all phosphorolytic reactions; however, the resulting compounds are much less stable and are hydrolyzed as soon as they dissociate from the surface of an enzyme. An 
important example is the oxidation of glyceraldehyde 3-phosphate in the presence of phosphate to form 1,3-diphosphoglycerate. Normally, the 1-phosphoryl group is then transferred to ADP to generate ATP. If arsenate is present and substitutes for phosphate, the resulting compound, 1-arseno-3 phosphoglycerate, is unstable and is quickly hydrolyzed to 3-phosphoglycerate. Thus, even though glyceraldehyde 3-phosphate continues to be oxidized, synthesis of ATP is blocked, and the cell is gradually depleted of energy. The energy used to form the arsenate intermediates is also lost to the cells.

Arsenite is a sulfhydryl agent which reacts rapidly with the thiol groups of proteins, resulting in enzyme inactivation (20). It is particularly active against dithiol groups, such as lipoic acid:
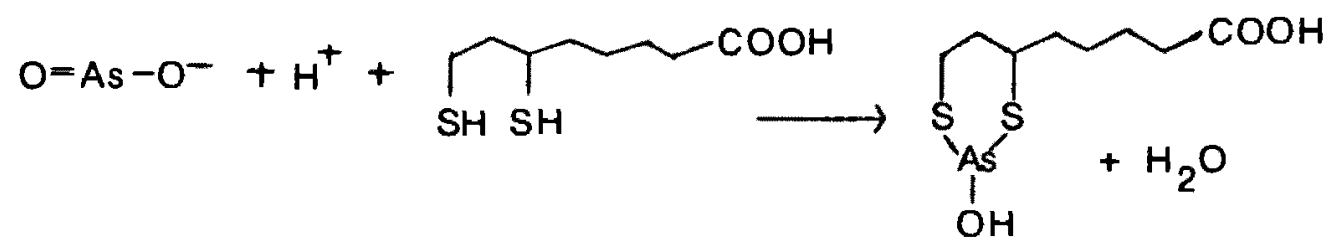

Lipoic acid is a component of the $\alpha$-ketoglutarate and pyruvate dehydrogenase complexes. Normally, these enzymes catalyze the oxidative decarboxylation of pyruvate and $\alpha$-ketoglutarate to form acetyl CoA and succinyl CoA, respectively. An acetyl group from pyruvate is transferred to a thiol group on lipoic acid. By preventing this reaction from occurring, arsenite causes the accumulation 
in the cell of pyruvate and other $\alpha$-keto acids and blocks complete oxidation of pyruvate via the tricarboxylic acid cycle.

Possible mutagenic effects of arsenite are suggested by the observation that low levels of arsenite inhibit excision repair in Escherichia coli following ultraviolet radiation by inhibiting formation of single-strand breaks in the DNA (9). Increased incidences of respiratory cancers have been reported in metallurgical, chemical and agricultural workers who are exposed to increased levels of arsenic (36). Although respiratory cancers are most common, cancers of the skin and internal organs have also been reported. Confirmatory carcinogenesis in laboratory animals is lacking, however (7). Based on the observation that arsenite reduces the ability of $\underline{E}$ coli to repair ultraviolet-induced damage, it may act as a co-carcinogen (34).

Bacteria resistant to arsenate and arsenite are commonly isolated from sewage, surface water and clinical infections. In one study of river and sewage-isolated enteric bacteria, $38.4 \%$ were found to be resistant to arsenite (35).

Different possible mechanisms of resistance include:

1. alterations of target sites

2. enzymatic degradation

3. enzymatic alteration 
4. altered transport

In E. coli, chromosomal mutations to arsenate resistance are known. This resistance reflects the fourth mechanism -- altered transport -- and involves two systems responsible for the uptake of phosphate $(34,40,42)$. The Pit system is the primary inorganic phosphate transport system in E. coli. It is constitutive and does not discriminate between phosphate and arsenate. Under limiting phosphate conditions, however, the phosphatespecific Pst system is induced, which more effectively discriminates between phosphate and arsenate. Chromosomal mutations that result in the loss of a functional Pit system (pit-) confer the arsenate-resistant phenotype (33) since, under this condition, only the phosphatespecific Fst system operates. Chromosomal resistance to arsenite has been less extensively studied, but alteration of the membrane-bound ATPase used for ATP synthesis has been suggested. This was based on the existence of an arsenite resistant mutant which was also uncoupled and therefore unable to grow on non-fermentable carbon sources (34).

The resistance to high concentrations of arsenite and arsenate observed in natural isolates, however, is associated with bacterial plasmids $(3,22,26,35)$. Plasmids conferring antibiotic resistances are often called 
$R$ factors and are frequently found in human coliform isolates. Resistances to other compounds, such as arsenite and arsenate, are often carried on these plasmids. In one study of 775 enteric plasmids isolated from various sources, over half exhibited resistance to various antibiotics, and $38.4 \%$ also carried resistance to arsenite (35) .

Mechanisms of plasmid-determined resistance have only recently been explored. Evidence suggests that resistance derives from separate plasmid-mediated efflux pumps for arsenate and arsenite. In one study, the $R$ factor $R 773$ (10) was introduced into E. coli strain AN 120 (23), an uncoupled mutant strain that has a defective $\mathrm{H}^{+}$ translocating ATPase. Thus, oxidative phosphorylation is blocked, and ATP is produced only from substrate-level phosphorylation. These cells were starved of endogenous energy reserves and passively loaded with arsenate. When glucose was added, arsenate was extruded. The rate of efflux was not inhibited by the addition of cyanide, which inhibits electron flow from NADH to $\mathrm{O}_{2}$, preventing formation of the proton motive force (PMF), but does not affect substrate-level phosphorylation. The addition of fluoride, which prevents substrate-level phosphorylation, reduced the rate of efflux. These observations suggest that the arsenate efflux pump is driven by the phosphate-bond energy of ATP and not by the FMF. 
Using the same strains and methods, a similar system was suggested for arsenite resistance (30). The two systems were found to be independent, since inactivation of one by mutation did not affect the activity of the other (3). Whether arsenite and arsenate are pumped out by the same efflux pump or two separate ones, as well as the components and their location, is unknown.

The fact that two plasmids confer resistance to a given substance is not proof of identical resistance mechanisms or of significant DNA homology. For example, using restriction enzyme analysis and DNA-DNA hybridization techniques, four genetically distinct tetracycline resistance determinants have been identified in a broad range of bacterial plasmids (18). These differences result in variations in expression of resistance to tetracycline and its analogs. Recognition sequences for four restriction enzymes were missing in some of the resistance markers studied, suggesting genetic dissimilarity. Colony blot DNA hybridization was performed against the tetracycline resistance marker in the transposon Tn10. The resistance determinants were divided into four genetically distinct classes based on DNA-DNA hybridization. These classes also show phenotypic differences in resistance to tetracycline and its analogs. This multiplicity of genetically distinct determinants specifying a common resistance suggests the possibility of parallel yet 
distinct biochemical pathways leading to the same phenotypic result.

Hybridization has also been carried out between the arsenic resistant plasmid $R 773$ and plasmid DNA from 15 other Gram-negative arsenite-resistant human isolates (22). Eight were highly homologous, while seven showed no evidence of hybridization. A few of the plasmids conferred resistance to one arsenic species but not the other. A conjugative plasinid in the Gram-positive bacterium Corynebacterium flaccumfaciens shows no genetic homology to R773 but also encodes inducible protection from arsenite and arsenate and codes for two proteins of the same size as those of $R 773$ (3). These results show that there are other, genetically distinct, plasmid-borne arsenite resistance determinants in addition to those represented by R773.

The present study is an investigation of the $R$ factor, R45, a $45 \mathrm{~kb}$ plasmid originally obtained from an enteric bacteria isolated from sewage (13). It confers resistance to both arsenite and arsenate, as well as to ampicillin, tetracycline, sulfonamides and low levels of streptomycin. The genes conferring resistances to both arsenite and arsenate have been localized to a $6.9 \mathrm{~kb}$ region of the plasmid DNA (24). This region was excised from the plasmid and ligated to the cloning vector, pBR322 (J.W. Myers, personal communication). 
The goals of the present study were 1) to construct a restriction map of the region of the $\mathrm{R} 45$ plasmid containing the arsenite-resistance determinant; 2) to determine the direction of transcription of the cloned fragment containing this region; and 3 ) to identify the proteins determined by the fragment. 
Bacterial Strains and Sources

Strain or Plasmid

E. coli $\mathrm{k}-12$

Strains

JM 105

C600

CSR 603

$\mathrm{CSH} 45$
Relevant Properties

thi, rpsL, endA,

SbcB15, hspR4

$\Delta(\underline{\text { lac }}-\mathrm{proAB})$,

[F', traD36, proAB, lacI,

$\underline{\text { lacz } \triangle M 15]}$

thi-1, supE 44 .

$F^{-}$, leuB6,

tonA21, thr-1

recA1, uvrA6,

phr-1, rPSL31.

thi-1 SUpE 44, $F^{-}$,

thr-1, leuB6, proA2

$A(\underline{l a c})$, thi, trpR, $(\lambda$ CI85757)
Source or

\section{Reference}

S. Falkow

31

21

J. Myers

41

41

This work

This work 
TABLE I

\section{TABLE OF ABBREVIATIONS}

$\begin{array}{ll}\text { amp } & \text { ampicillin } \\ \text { asi } & \text { arsenite } \\ \text { asa } & \text { arsenate } \\ \text { LB } & \text { Luria broth } \\ \text { LA } & \text { Luria agar } \\ \text { lac } & \text { lactose operon } \\ \text { IPTG } & \text { isopropyl- } \beta \text {-D-thiogalactoside } \\ \text { MOPS } & \text { morpholinopropane sulfonic } \\ \text { F' } & \text { acid } \\ & \text { carrying the E. coli sex factor } \\ \text { r } & \text { insertion } \\ \text { S } & \text { resistant } \\ \text { MCS } & \text { sensitive } \\ \text { SDS } & \text { multiple cloning site } \\ \text { kb } & \text { sodium dodecyl sulfate } \\ \text { Kdal } & \text { kilobases } \\ \text { MIC } & \text { kilodaltons } \\ \text { RNAP } & \text { minimal inhibitory } \\ \text { PMF } & \text { concentration } \\ \text { X-gal } & \text { RNA polymerase } \\ & \text { proton motive force } \\ & \text { 5-bromo-4-chloro-3-indolyl- } \beta \text {-D- } \\ \text { galactoside }\end{array}$


Glycerol stocks and strains constructed in this study were verified on appropriate selective media prior to use. Short-term working stocks were maintained on these media at $4^{\circ} \mathrm{C}$. Long-term stacks were stored in $50 \%$ glycerol at $-20^{\circ} \mathrm{C}$.

\section{Growth Media}

All chemicals were of analytical grade and were purchased from various sources. The standard liquid medium used for growth studies was Luria broth (21), supplemented as indicated. For solid media, $15 \mathrm{~g}$ agar was added before autoclaving. Since phosphate competes with arsenate for uptake, arsenate resistance was assayed on morpholinopropane sulfonic acid (MOPS) medium:

\begin{tabular}{|c|c|}
\hline MOPS buffer ( $\mathrm{pH} 7.2)$ & 40.0 \\
\hline $\mathrm{Na}_{2}=\mathrm{HASO}_{4}$ & 50.0 \\
\hline $\mathrm{NaCl}$ & 50.0 \\
\hline $\mathrm{MgSO}_{4} \cdot 7 \mathrm{H}_{2} \mathrm{O}$ & 0.5 \\
\hline$\left(\mathrm{NH}_{4}\right)_{2} \mathrm{SO}_{4}$ & $0.1 \%$ \\
\hline $\mathrm{K}_{2} \mathrm{HPO}_{4}$ & 1.0 \\
\hline glucose & $0.5 \%$ \\
\hline
\end{tabular}

required growth factors

for each strain

Arsenite resistance was assayed on Davis minimal medium (Difco) containing $10 \mathrm{mM}$ sodium arsenite, $0.5 \%$ glucose and the required growth factors of the strain being assayed. Top agar was prepared as for Luria agar, with the agar concentration reduced to $0.7 \%$. 
Isolation of Plasmid DNA

Plasmid DNA was extracted from verified strains by the method of Birnboim and Doly (1). The centrifuged cell paste was re-suspended in $10 \mathrm{ml} 25 \mathrm{mM} \mathrm{Tris}-\mathrm{Cl}$ (pH 8), $10 \mathrm{mM}$ $\mathrm{NazEDTA}$ and $1 \%(\mathrm{w} / \mathrm{v})$ glucose. To lyse the cells, $20 \mathrm{ml}$ $0.2 \mathrm{M} \mathrm{NaOH}$ containing $1 \%$ SDS was added. At high $\mathrm{pH}$, plasmid DNA remains covalently closed, while the linear chromosomal fragments become single-stranded. A 5 M acidified potassium acetate solution (15) was added to lower the $\mathrm{pH}$ and precipitate proteins, high molecular weight RNA and single-stranded DNA. The plasmid DNA renatured to the supercoiled form and remained in the supernatant. The precipitate was removed by centrifugation, and the plasmid DNA was precipitated with two volumes of $95 \%$ ethanol. After centrifugation the pellet was dissolved in 6 ml TE buffer (15).

To remove contaminating chromosomal DNA, RNA, and proteins, the solution was centrifuged in a cesium chloride density gradient containing $0.6 \mathrm{ml}$ ethidium bromide (EtBr) (10 mg/ml) to purify the plasmid DNA (2). Ethidium bromide intercalates into the DNA, reducing its density. Since linear and open circular DNA are not as physically constrained as the covalently closed circular plasmid DNA, the first two forms bind more ethidium bromide molecules than the third, become less dense, and band with a different bouyant density. The DNA was centrifuged in the 
Ti 50 rotor of a Beckman preparative ultracentrifuge for 36 hours at 45,000 rpm. DNA bands were visualized with an ultraviolet lamp, and the lower plasmid DNA band was extracted. Ethidium bromide was removed from the plasmid DNA solution by extraction with isopropanol saturated with $5 \mathrm{M} \mathrm{NaCl}$ (4). Remaining impurities were removed by ethanol precipitation of the DNA in two volumes of ethanol in the presence of $2.5 \mathrm{M}$ ammonium acetate, and the pellet was suspended in 100 ul TE buffer containing 1 unit/m 1 RNAse $T_{1}$ (ternase) (4).

\section{Isolation of Bacteriophage $\lambda$ DNA}

E. Coli CSH 45 contains the prophage $\lambda$ cI857S7 (4). This viral strain has two mutations, cI857 and 57. The cI repressor gene is responsible for inhibiting the expression and replication of $\lambda$ and keeping it in the lysogenic state. The cI857 mutation results in production of a temperature sensitive repressor. The $\mathbf{S 7}$ mutation renders the phage lysis-deficient, and it continues to multiply inside the cell. E. coli $\mathrm{CSH} 45$ was grown on agar at $30^{\circ} \mathrm{C}$ and $42^{\circ} \mathrm{C}(4)$. Cells picked from colonies showing no growth at the non-permissive temperature were grown in LB at $32^{\circ} \mathrm{C}$ for one hour, and the temperature was increased to $43^{\circ} \mathrm{C}$ for 20 minutes to inactivate the repressor and induce the lytic cycle.

The cultures were allowed to grow for an additional 
three hours. They were then centrifuged and suspended in $10 \mathrm{ml} \lambda$ diluent (4). One ml chloroform was added to lyse the bacterial cells. The phage was separated from cellular debris by passage through a CsCl density block gradient (4). A lysate was laid over two CsCl solutions having densities of 1.6 and 1.4 , placed in a Eeckman SW 65 swinging bucket rotor, and centrifuged in the Beckman preparative ultracentrifuge for two hours at 30,000 rpm. The phage, with a density of about 1.5 , collected at the interface between the two $\mathrm{CsCl}$ solutions and was removed. The DNA was isolated by treating the lysate with SDS, followed by 5M potassium acetate. Proteins were removed by centrifugation for 30 minutes in a microfuge. The $\lambda$ DNA was precipitated with ethanol and suspended in 1

ml ternase. Absorbancy readings were taken in a Beckman spectrophotomer at $260 \mathrm{~nm}$ to determine the concentration of DNA ( 1 O.D.zeo=50 ug/ml). Portions of the DNA were diluted with ternase to give standards of $10,5,2.5,1.25$, and $0.625 \mathrm{ug} / \mathrm{ml}$. These were used to estimate DNA concentration based on EtBr fluorescence.

Saran Wrap was placed across a Chromato-vuen transilluminator in a darkroom (15). The prepared standards and DNA samples were pipetted onto the Saran Wrap and mixed with 5 ul of EtBr ( $2 \mathrm{mg} / \mathrm{ml})$. Ultraviolet light was transmitted through the samples, and photographs were taken with a Polaroid MP-4 Land camera using a yellow 
filter and Polaroid Type $57 \mathrm{film}$. The concentration of DNA was then determined by comparing the fluorescence of the samples with that of the known standards.

\section{Digestion of DNA with Restriction Endonucleases}

Lyophilized restriction endonucleases were reconstituted according to manufacturer's instructions and kept at $-20^{\circ} \mathrm{C}$. Restriction digests were carried out at $370^{\circ}$ for two hours. Different restriction enzymes require different salt concentrations for maximum activity. When sequential restriction digests were performed, the enzyme requiring lower salt conditions was used first. Then the salt concentration was increased according to the following table. This is based on a volume of 15 ul following the first restriction, to be increased to 20 ul with ternase following buffer adjus tment :

\begin{tabular}{|c|c|c|c|}
\hline $\begin{array}{c}\text { Stock } \\
\text { solution }\end{array}$ & $\begin{array}{c}\text { Low } \\
\text { to Medium } \\
\end{array}$ & $\begin{array}{l}\text { Low } \\
\text { to High }\end{array}$ & $\begin{array}{l}\text { Medium } \\
\text { to High } \\
\end{array}$ \\
\hline $4 \mathrm{M} \mathrm{NaCl}$ & $0.25 \mathrm{ul}$ & $0.5 \mathrm{ul}$ & 0.3125 ul \\
\hline $\begin{array}{rl}1 \mathrm{M} & \text { Tris-Cl, } \\
\mathrm{pH} & 7.5\end{array}$ & $0.05 \mathrm{ul}$ & $0.85 \mathrm{ul}$ & 0.85 \\
\hline
\end{tabular}


Electrophoresis of DNA Fragments

Agarose gels ranging from 0.7 to $1.2 \%$ (w/v) were prepared in tris-acetate electrophoresis buffer (15) containing 0.25 ug/ml of ethiduim bromide (39). Samples containing 100-200 ng DNA and one-quarter volume of DNA tracking dye (1) were run in a horizontal slab gel apparatus (16) at $3 \mathrm{~V} / \mathrm{cm}$. The running time varied with the specific procedure.

\section{Isolation of DNA Fragments}

Digested DNA was separated by electrophoresis, and the gel was placed on an ultraviolet transilluminator to visualize the bands. The gel was sliced, and a strip of Whatman DE 81 DEAE cellulose paper was inserted in front of the desired band (5). The DNA was moved onto the paper by electrophoresis at $100 \mathrm{~V}$ for 30 minutes. The paper was then removed, packed into the barrel of a disposable plastic $1 \mathrm{ml}$ syringe and placed in a $15 \mathrm{ml}$ Corex centrifuge tube. The paper was first washed by pipetting $200 \mathrm{ul}$ of $0.1 \mathrm{M} \mathrm{NaCl}, 0.1 \mathrm{mM}$ EDTA, $10 \mathrm{mM}$ Tris-Cl (pH 8) into each syringe and centrifuging at $2000 \mathrm{rpm}$ for 30 seconds in a Sorval GLC-1 centrifuge. This procedure was repeated twice and the eluates discarded. To remove the DNA from the paper, a $1.5 \mathrm{ml}$ polypropylene tube was placed in the Corex tube to catch the eluate, and the paper was washed by adding 100 ul of a $1.0 \mathrm{M} \mathrm{NaCl}, 0.1 \mathrm{M}$ EDTA, $10 \mathrm{mM}$ 
Tris-cl ( $\mathrm{pH}$ 8.0) solution, followed by centrifugation for 30 seconds at $2000 \mathrm{rpm}$. This was repeated three times, for a total DNA eluate of $400 \mathrm{ul}$. Two volumes of $95 \%$ ethanol were added to the eluate, the tubes were placed in a dry ice-ethanol bath for five minutes to precipitate the DNA and then centrifuged in a microfuge for 30 minutes.

The pellet was suspended in $100 \mathrm{ul}$ ternase and mixed with an equal volume of a $1: 1(v / v)$ mixture of phenol equilibrated with TE buffer and chloroform mixed 24:1 $(v / v)$ with isoamyl alcohol (15) and then centrifuged 15 seconds in a microfuge to separate the organic and aqueous layers. The upper aqueous layer was removed to a new tube. To maximize DNA recovery, the remaining organic layer was re-extracted with 100 ul TE buffer. The upper aqueous layer was again removed and mixed with the first aqueous portion. Residual phenol was then removed by mixing with an equal volume of chloroform and centrifuging as before. The aqueous layer was removed, and the DNA was precipitated with ammonium acetate and ethanol, as previously described.

\section{Construction of Recombinant Plasmids}

Vector DNA was digested with Hind III, followed by Eco RI, using buffers and conditions previously described. The enzymes were then removed by phenol extraction. Ligations were carried out using $200 \mathrm{ng}$ of 
each vector DNA with an equimolar amount of isolated fragment DNA. A tube containing $400 \mathrm{ng}$ of vector DNA digested with Hind III alone was included as a ligase control.

Two units of T4 DNA ligase were added to each reaction mixture, along with $10 \times$ ligation buffer (15):

$$
\begin{aligned}
& 0.5 \mathrm{M} \text { Tris-Cl, } \mathrm{pH} 7.4 \\
& 0.1 \mathrm{M} \mathrm{MgSO} \\
& 10.0 \mathrm{mM} \text { spermidine } \\
& 0.1 \mathrm{M} \text { dithiothreitol } \\
& 10.0 \mathrm{mM} \text { adenosine triphosphate } \\
& 1.0 \mathrm{mg} / \mathrm{ml} \text { bovine serum albumin }
\end{aligned}
$$

The reaction mixtures were incubated at $4^{\circ} \mathrm{C}$ for 12 hours.

Ligated plasmids were then used to transform host cells.

\section{Transformation}

E. Coli JM 105 and CSR 603 were prepared for transformation (14) by growing cultures to a density of $5 \times$ $10^{7}$ cells/ml. Cell density was determined using a Klett-Summerson Photoelectric Colorimeter, Model 800-3, with a red \#66 filter. The culture was chilled on ice for 10 minutes and then centrifuged at 4000 rpm at $00 \mathrm{C}$ for five minutes. The pellets were suspended in one-half the original culture volume in a cold $\left(4^{\circ} \mathrm{C}\right) 50 \mathrm{mM} \mathrm{CaC1}$ solution, centrifuged again and resuspended in $\mathrm{CaCl}_{2}$ at one-fifteenth the original volume. Aliquots of $0.2 \mathrm{ml}$ were stored at $4^{\circ} \mathrm{C}$ for 24 hours. Up to $40 \mathrm{ng}$ of plasmid DNA was added to each tube. The tubes were kept on ice for 30 
minutes and then transferred to a $42^{\circ} \mathrm{C}$ water bath for two minutes. Then $1.0 \mathrm{ml} \mathrm{LB}$ was added and the cells were incubated for two hours at $370^{\circ} \mathrm{C}$ to allow for expression of plasmid-carried ampicillin resistance. Successful transformation was detected by plating the cells on Luria agar containing ampicillin at a final concentration of 50 $\mathrm{ug} / \mathrm{ml}$.

When transformation was carried out with pUC vectors, ampr transformants containing vectors with inserts could be distinguished from those without inserts by the following procedure. Approximately $10^{\circ}$ cells from each transformation tube were plated on LA containing amp,

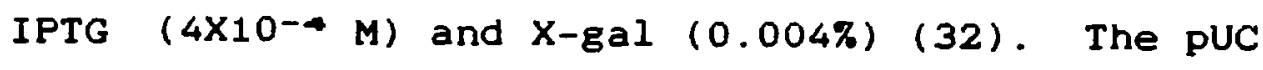
vector codes only for the promoter-proximal region of $\beta$-galactosidase ( $\alpha$ donor) and the JM105 F' plasmid specifies a $\beta$-galactosidase functional only in the promoter-distal region ( $\omega$ donor); the two complementary polypeptide chains can associate to produce active $\beta$-galactosidase (intracistronic complementation). Such activity can be detected by the production of the insoluble blue dye dibromodichloroindigo (19) when $\mathrm{X}-\mathrm{gal}$ is hydrolyzed by the enzyme. If the transformant has an insert in the MCS, the coding region for the promoterproximal $\beta$-galactosidase is interrupted and no $\alpha$ donor polypeptide is made. Transformants containing pUC vector inserts produce white colonies under these conditions. 
Three ml of molten top $\mathrm{L}$ agar was mixed with $0.2 \mathrm{ml}$ of transformed cells, and 100 ul of 0.1 M IPTG was added, along with 50 ul of $2 \% \mathrm{X}$-gal (dissolved in $\mathrm{N}, \mathrm{N}$-dimethylformamide) (37). The top agar was poured over LA previously spread with ampicillin. The plates were incubated for 12 hours at $37 \circ \mathrm{C}$.

\section{Minimal Inhibitory Concentration}

The two E. coli host strains used, JM 105 and CSR 603, and two recombinant-plasmid-bearing strains, JM 105 (pUC84) and CSK 603(pUC84), were grown overnight in $10 \mathrm{ml}$ LB, with and without the addition of $1 \mathrm{mM}$ arsenite. These were subcultured $1: 100$ into side-arm flasks containing the same media and shaken at $37{ }^{\circ} \mathrm{C}$ until they reached a density of $2.5 \times 10^{\circ}$ cells/ml. From each flask, 50 ul was spread over the surface of LA plates containing the following concentrations of arsenite: $2,4,6,8,10,12,15$ and 20 mM. The plates were incubated for 48 hours at $370 \mathrm{C}$, and the colonies were counted. The lowest concentration of arsenite on which no growth was observed was taken to be the minimal inhibitory concentration of arsenite for that strain $(32,34)$.

\section{Induction of Arsenite Resistance by IPTG}

The E. coli strains JM 105, JM 105 (pUC8), JM 
105 (pUC84) and JM 105(PUC96) were grown overnight in $10 \mathrm{ml}$ LB, with the following additions for each strain:

$$
\begin{aligned}
& \text { 1. None } \\
& \text { 2. } 1 \mathrm{mM} \text { arsenite } \\
& \text { 3. } 10^{-3} \text { M IPTG (25) }
\end{aligned}
$$

Cultures were diluted 1:100 into the same media in side-arm flasks and shaken at $370^{\circ} \mathrm{C}$ until they reached a density of $1.5 \times 10^{\circ}$ cells/ml. This dilution and subsequent growth period was repeated. The cultures were challenged by the addition of arsenite to a final concentration of $15 \mathrm{mM}$, and the growth of each was monitored over a period of several hours.

Restriction Mapping of the Arsenite Resistance Fragment

Aliquots of $0.5 \mathrm{ug}$ of the isolated 445 fragment DNA were digested with the restriction enzymes Pvu I, Bgl II, Sph I and Sal I. Resulting fragments were separated by electrophoresis through $1.0 \%$ agarose for two hours at 100 V. The distance from the origin of each separated band was measured in millimeters, and compared with a standard curve of the log molecular weight against the distance traveled by the $\lambda$ DNA Hind III-digested fragments. By this means, the molecular weights of the digestion products were estimated (16).

A portion of each single digest was then subjected to a separate, second digestion with each of the remaining three enzymes under analysis. The digestion products of 
the second digestion were separated by electrophoresis and the fragment sizes estimated as described for the first.

\section{Identification of Plasmid-Encoded Proteins}

The recA- uvr- genotype of the E. coli strain CSK 603 (31) was confirmed by spreading $10^{\text {e }}$ cells of an overnight culture grown from a single CSR 603 colony on LA and irradiating with a total uV dose of $0.5 \mathrm{~J} / \mathrm{m}^{2}$. The plates were incubated for 24 hours at $370^{\circ} \mathrm{C}$ in the dark (A. Sancar and G. Sancar, personal communication). Plates having fewer than 100 survivors were used in the following procedures.

Recombinant plasmids and intact pUc vectors were transforned into E. coli CSR 603. Cultures were grown overnight in LB with the following additions. Ampicillin was included to select against variants that may have lost the plasmid.

\section{Culture}

603

603 (PUC8)

603 ( pUC84), uninduced

603 (pUC84), induced

$603($ pUC96), uninduced

603 (pUC96), induced

\section{Additions}

none

$50 \mathrm{ug} / \mathrm{ml}$ amp

$50 \mathrm{ug} / \mathrm{ml}$ amp

$50 \mathrm{ug} / \mathrm{ml}$ amp $+10 \mathrm{mM}$ asi

$50 \mathrm{ug} / \mathrm{ml}$ amp

$50 \mathrm{ug} / \mathrm{ml}$ amp $+10 \mathrm{mM}$ asi

The cultures were diluted 1:100 into $10 \mathrm{ml}$ of the same media without ampicillin in side-arm flasks and grown to a 
density of $2 \times 10^{*}$ cells/ml. The cultures were diluted 1:100 and grown to the same cell density to insure that cells were in log phase before proceeding. All cultures were centrifuged at $4000 \mathrm{rpm}$ for five minutes, and the pellets were suspended in $10 \mathrm{ml}$ Davis Minimal broth. They were then irradiated with swirling in a petri dish, for a total UV dose of $5 \mathrm{~J} / \mathrm{m}^{2}$, to inactivate chromosomal DNA. The suspensions were centrifuged and the pellets resuspended in $10 \mathrm{ml}$ LB with the additions previously described. The cultures were incubated for three hours, $0.1 \mathrm{ml}$ of a freshly made cycloserine solution (200 ug/ml) was added, and the cultures were incubated for 12 hours. From each culture, $1.5 \mathrm{ml}$ was centrifuged in a microfuge for $f$ ive minutes, and the cells were resuspended in 40 ul of lysing buffer ( 8$)$ :

$$
\begin{aligned}
& 0.05 \text { M Tris-Cl, } \mathrm{pH} 6.8 \\
& 2 \% \text { sDs } \\
& 15 \% \text { glycerol } \\
& 2 \% 2 \text {-mercaptoethanol } \\
& 0.005 \% \text { bromophenol blue }
\end{aligned}
$$

These mixtures were boiled for three minutes to lyse the cells and then stored at $4^{\circ} \mathrm{C}$ until needed.

Polyacrylamide gels were used for the separation of proteins by the method of Laemmli (12). Stock solutions were as follows: 
1. $30 \%$ acrylamide

2. $4 X$ running gel buffer (1.5 M Tris-Cl, $\mathrm{pH} 8.8)$.

3. $4 \mathrm{X}$ stacking gel buffer (0.5 M Tris-Cl, pH 6.8).

4. $10 \%(w / v)$ sodium dodecyl sulfate (SDS)

5. $10 \%(w / v)$ ammonium persulfate (APS)

6. Commercial stock of TEMED

$\left(\mathbf{N}, \mathbf{N}, \mathbf{N}^{\prime}, \mathbf{N}^{\prime}\right.$-tetramethylethylenediamine)

7. Tank buffer $10.025 \mathrm{M}$ Iris-Cl, $\mathrm{pH} 8.3,0.192 \mathrm{M}$ glycine and $0.1 \%$ SUS).

8. $1 \%$ Coomassie blue R-250 stain stock. This stock was used to make a $0.125 \%$ Coomassie blue, $50 \%$ methanol, $10 \%$ acetic acid stain for gels.

9. 50\% methanol, $10 \%$ acetic acid (primary destaining solution).

10. $5 \%$ methanal, $7 \%$ acetic acid (secondary destaining solution).

Glass plates with $1.0 \mathrm{~mm}$ spacer bars were sealed with $1.0 \%$ agarose to form a sandwich $16.5 \times 19 \mathrm{~cm}$. A $12.5 \%$ separating gel solution was prepared:

$12.5 \mathrm{ml}$ monomer solution

$7.5 \mathrm{ml} 4 \mathrm{X}$ running gel buffer

$0.3 \mathrm{ml} 10 \%$ SDS

9.7 of $\mathrm{H}_{2} \mathrm{O}$

To this, 10 ul TEMED and $0.75 \mathrm{ml}$ APS were added. This solution was quickly delivered into the glass sandwich to within $5 \mathrm{~cm}$ of the top, and $1.0 \mathrm{ml}$ isopropanol was layered 
over the gel to form a level surface. The gel was allowed to polymerize two hours. A stacking gel solution was prepared :

$$
\begin{aligned}
& 1.33 \mathrm{ml} \text { monomer solution } \\
& 2.5 \mathrm{ml} 4 \mathrm{X} \text { stacking gel buffer } \\
& 0.1 \mathrm{ml} 10 \% \mathrm{SDS} \\
& 6.1 \mathrm{ml} \mathrm{H}_{2} \mathrm{O}
\end{aligned}
$$

Five Ul TEMED and $0.25 \mathrm{ml}$ APS were added, the sandwich was filled with this solution, and a 16-well comb was inserted. The stacking gel was allowed to polymerize at least one hour. The sandwich was sealed in place in a Watson vertical gel apparatus with $1.0 \%$ agarose. Ten ul of each sample ( 1.5 ug protein) and protein standard ( 1.0 ug protein) were pipetted into the wells, and the gel was electrophoresed at $70 \mathrm{~V}$ constant voltage until the dye

\begin{tabular}{|c|c|c|}
\hline Mixture & Containing & $\frac{\text { Molecular }}{\text { weight }}$ \\
\hline A & $\begin{array}{l}\text { lactalbumin } \\
\text { carbonic anhydrase }\end{array}$ & $\begin{array}{l}14.2 \mathrm{Kdal} \\
29.0 \mathrm{Kdal}\end{array}$ \\
\hline B & $\begin{array}{l}\text { Trypsin inhibitor } \\
\text { glyceraldehyde-3-phosphate } \\
\text { dehydrogenase } \\
\text { bovine serum albumin }\end{array}$ & $\begin{array}{l}\mathrm{e}^{20.1 \mathrm{Kdal}} \\
36.0 \mathrm{Kdal} \\
66.0 \mathrm{Kdal}\end{array}$ \\
\hline$c$ & $\begin{array}{l}\text { trypsinogen } \\
\text { egg albumin }\end{array}$ & $\begin{array}{l}24.0 \mathrm{Kdal} \\
45.0 \mathrm{Kdal}\end{array}$ \\
\hline
\end{tabular}
front began to enter the separating gel. The voltage was then increased to $170 \mathrm{~V}$, and the gel was run 4-5 hours (39). Frotein standards used were: 
Gels were stained by placing them in a glass dish and covering them with $100 \mathrm{ml}$ Coomassie blue stain. The pan was shaken on a Kraft rotary shaken at 60 rpm for one hour. The gel was drained, immersed in $100 \mathrm{ml}$ of primary destaining solution and shaken for one hour. The gel was again drained, covered with $100 \mathrm{ml}$ secondary destaining solution and shaken overnight.

Alternatively, gels were stained with silver (43), either alone or following Coomassie blue (9). The gel was soaked overnight in $50 \%$ methanol to fix the proteins, rehydrated under running water for one hour and drained. The silver staining solution was prepared by mixing $21 \mathrm{ml}$ of $0.36 \% \mathrm{NaOH}$ with $1.4 \mathrm{ml}$ of $14.8 \mathrm{M} \mathrm{NH}$ OH. The solution was stirred while $4.0 \mathrm{ml}$ of stock AgNO solution $(4.0 \mathrm{~g}$ AgNOO dissolved in $20 \mathrm{ml} \mathrm{H}_{2} \mathrm{O}$ ) was added dropwise, to prevent precipitation. The solution was poured over the gel, and the gel was then agitated on the rotary shaker for 15 minutes. The gel was rinsed for 30 minutes under running water and then drained. A developing solution containing $0.005 \%(w / v)$ citric acid and $0.002 \%(v / v) 37 \%$ formaldehyde was freshly prepared and poured over the drained gel. The gel was then agitated over a white background until protein bands began to appear. The process was stopped by pouring 50\% methanol over the drained gel and agitating for 15 minutes. Protein size was estimated from a plot of the log of the size of the protein 
standards in kilodaltons against the distance traveled from the origin in millimeters.

Stained gels were photographed with a Polaroid $4 \times 5$ Land camera using Polaroid Type 55 positive/negative film. The gels were rinsed in running water overnight to remove all traces of methanol, soaked in an aqueous solution of $1 \%$ glycerol and $10 \%$ acetic acid for 45 minutes, placed on either Whatman 3 MM filter paper or cellophane sheets, and dried at $80^{\circ} \mathrm{C}$ for two hours in a BioRad Model $224 \mathrm{Gel}$ slab Dryer. 
RESULTS

Isolation and Ligation of Arsenic-kesistant Fragment DNA

The source of the insert DNA used to construct

recombinant plasmids in this study was the previously

constructed plasmid, pEH, containing the arsenic-resistance region from R45 ligated into the cloning vector, pBR (Jahr Myer:, pergonal communication). Plasmid DNA was isolated by methods previously described. Plasmid DNA yield was routinely $1.0-2.0 \mathrm{mg}$ per liter of starting culture. The R45-derived fragment was then separated from pBR by double digestion with Hind III and Eco RI. Each cloning vector was subjected to a double digest with Hind III and Eco RI and $200 \mathrm{ng}$ was mixed with $500 \mathrm{ng}$ of the fragment and ligated with T4 ligase. After ligation, the DNA was used to transform E. coli strain JM 105.

\section{Transformation of Recombinant Plasmids}

Transformants were selected by mixing $0.3 \mathrm{ml}$ transformed cultures with IPTG and X-gal in top agar and pouring this over LA spread with ampicillin. Blue colonies revealing a functional $\beta$-galactosidase and thus an intact vector were rejected. White colonies reflect an insert in the MCS of the vector. These constituted up to $20 \%$ of 
observed colonies. White colonies were picked and spread on LA containing ampicillin and $10 \mathrm{mM}$ arsenite, to confirm the asir phenotype. Short-term working stocks were maintained on this medium at $4^{\circ} \mathrm{C}$. Since the puc vectors differ only in their orientation of the MCS, the fragment insertion in pucs should have the opposite orientation of the insert in pucg.

Confirmation of Recombinant Plasmids

To confirm that the resistance was due to the presence of a plasmid with a molecular weight equal to the sum of those of the inserted fragment $(6.9 \mathrm{~kb})$ and the puc vector ( $2.7 \mathrm{~kb})$, plasmid DNA was extracted from several separately maintained clones of both supposed orientations. This DNA was digested with Hind III and Eco RI, and samples containing 100-200 ng DNA were electrophoresed through a $0.7 \%$ agarose gel. Double-digested PUC and PEH plasmid DNA were included in the gel as size markers. Bacteriophage $\lambda$ DNA was digested with Hind III, producing seven fragments of known size $-23.67,9.67,6.66,4.26,2.30,1.96$, and $0.59 \mathrm{~kb}$ respectively. This mixture was used as size markers in this and other agarose gels. Fig. 1 shows that all recombinant plasmids contained an insert of the expected size.

To confirm that the recombinant plasmids derived from pucr and pUC9 did indeed contain the 845 fragment in 


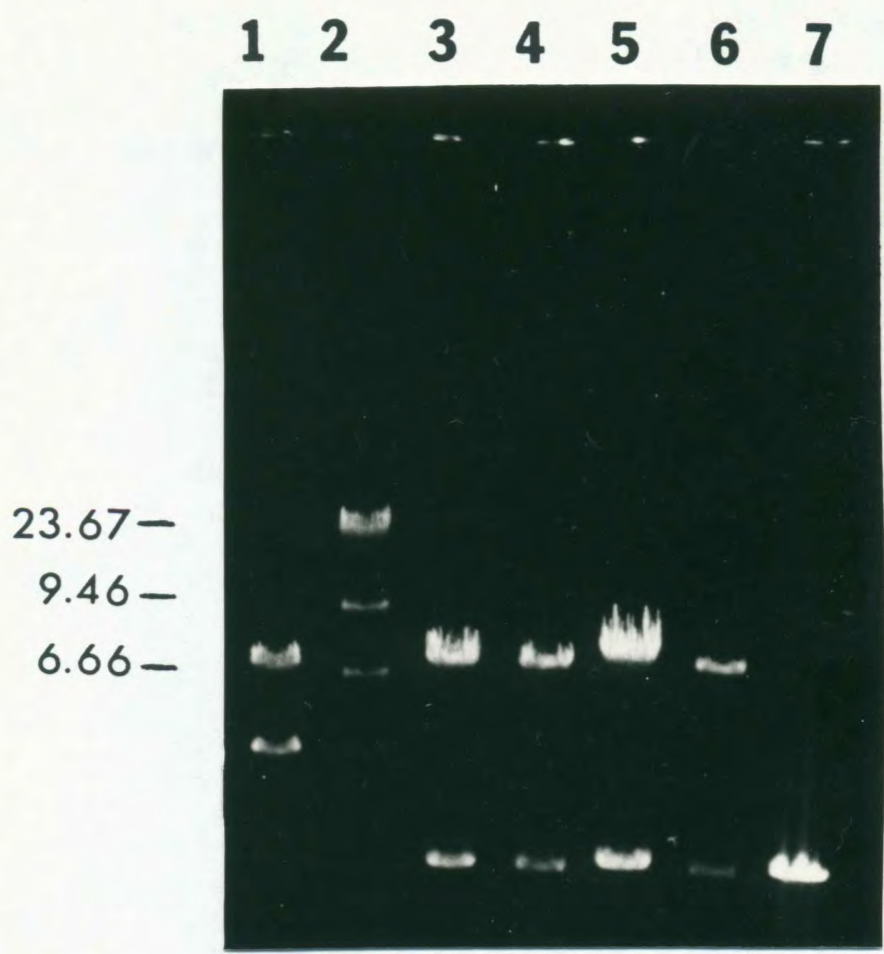

Figure 1. Electrophoretic Analysis of Restriction Digests of Recombinant Plasmids

Plasmid DNA was removed from transformed E. coli JM 105 strains and sequentially digested with EcoR I and Hind III. Lane 1, pEH; lane $2, \lambda \mathrm{H}$; lane 3, 105(pUC83); lane 4, 105(pUC84); lane 5, 105(pUC92); lane 6, 105(pUC96); lane 7, pUC8. Size standards are shown on the left in kilobases. 
opposite orientation, plasmid LNA was digested with PVU I. The results of this digest are shown in Fig. 2. There are two known Pvu I sites in the pUC vectors outside the MCS at nucleotides 280 and 2070 , and none inside the MCS. If a puc vector is linearized by deletion of the MCS, Fuu I cuts either vector into three fragments of $0.12,0.9$ and $1.6 \mathrm{~kb}$ (personal communication, Bethesda Research Laboratories):

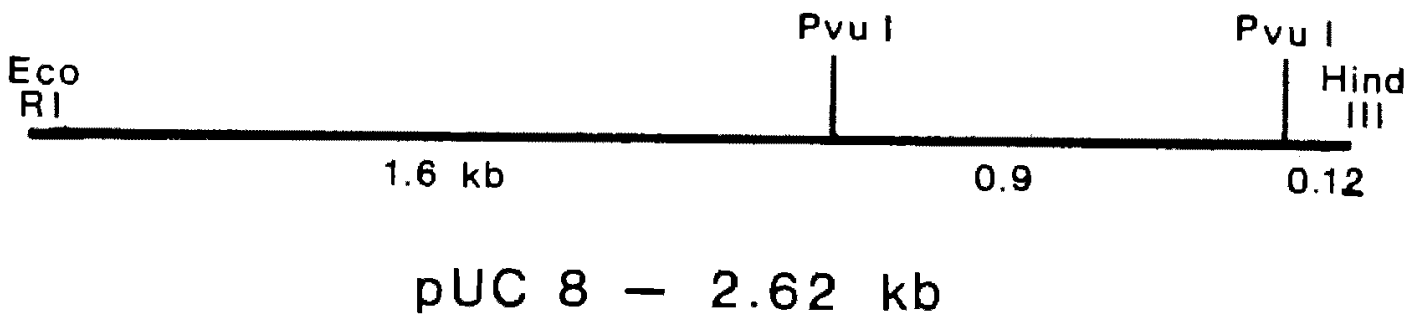




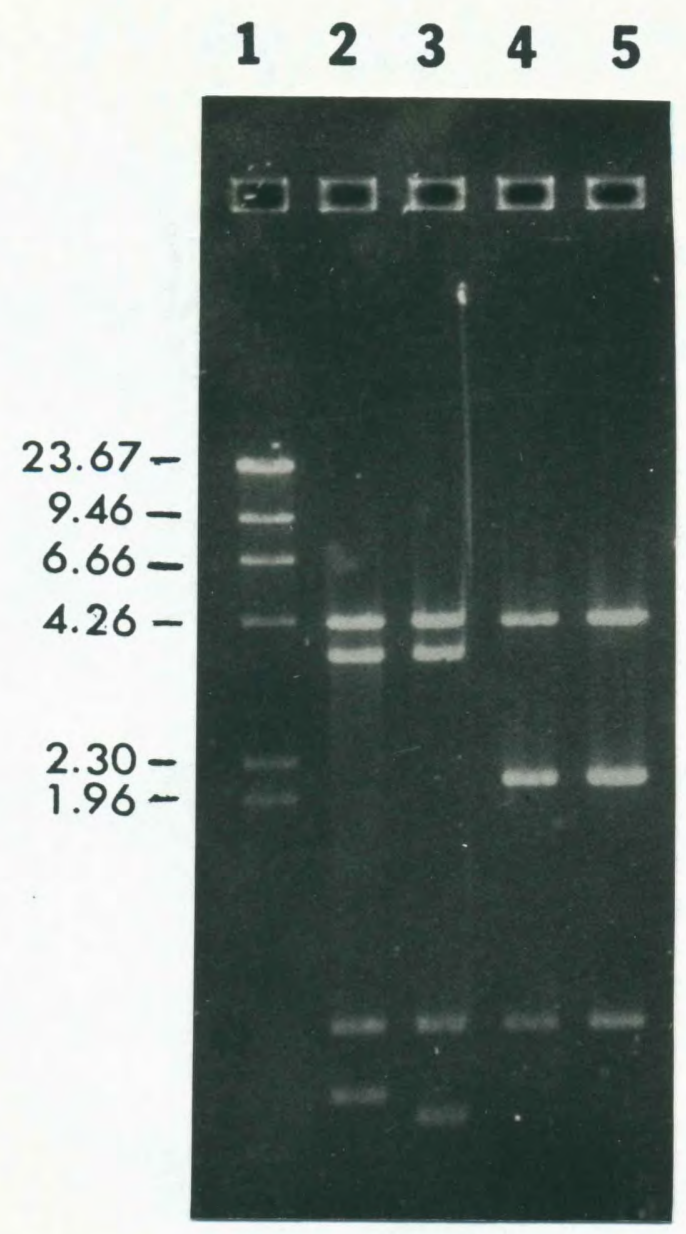

Figure 2. Opposite Orientation of Insertions in Recombinant Plasmids

Recombinant plasmid DNA from two clones in each supposed insertion orientation were digested with PVu I. Lane 1 , $\lambda \mathrm{H}$; lane 2, 105(pUC83); lane 3, 105 (pUC84); lane 4, 105 (pUC92); lane 5, 105(pUC96). In lane 3, there appears to be a small deletion in the smallest fragment of the vector. In lanes 4 and 5 , the 2.2 and $2.12 \mathrm{~kb}$ fragments are seen as a doublet. Size standards are indicated on the left in kilobases. 
It can be seen that, with any insert, the $0.9 \mathrm{~kb}$ fragment will be retained, and the remaining two fragments will vary in size. As shown in Fig. 2, this is indeed the case. In both orientations, the $0.9 \mathrm{~kb}$ fragment is conserved, along with a $4.3 \mathrm{~kb}$ fragment, indicating that segment is internal to any Pvu I sites within the insertion. Moving in either direction from this $4.3 \mathrm{~kb}$ segment, one finds two remaining fragments that will vary in size, representing the remaining termini of the inserted fragment plus any pUC DNA between the MCS borders and the first Pvu I site encountered in the vector. The fragment sizes are:

\begin{tabular}{cc} 
pUC8 clones & pUC9 clones \\
\hline $0.6 \mathrm{~kb}$ & $0.9 \mathrm{~kb}$ \\
0.9 & 2.1 \\
3.72 & 2.12 \\
4.3 & 4.3
\end{tabular}

These results are illustrated in Fig. 3. 
Figure 3. Pvu I Restriction Map of Recombinant Plasmids

The Pvu I restriction sites (P) are shown on a recombinant plasmid in each orientation. The Eco RI (E) and Hind III (H) termini of the vector (thick line) are also indicated. The fragment sizes are shown in kilobases. 

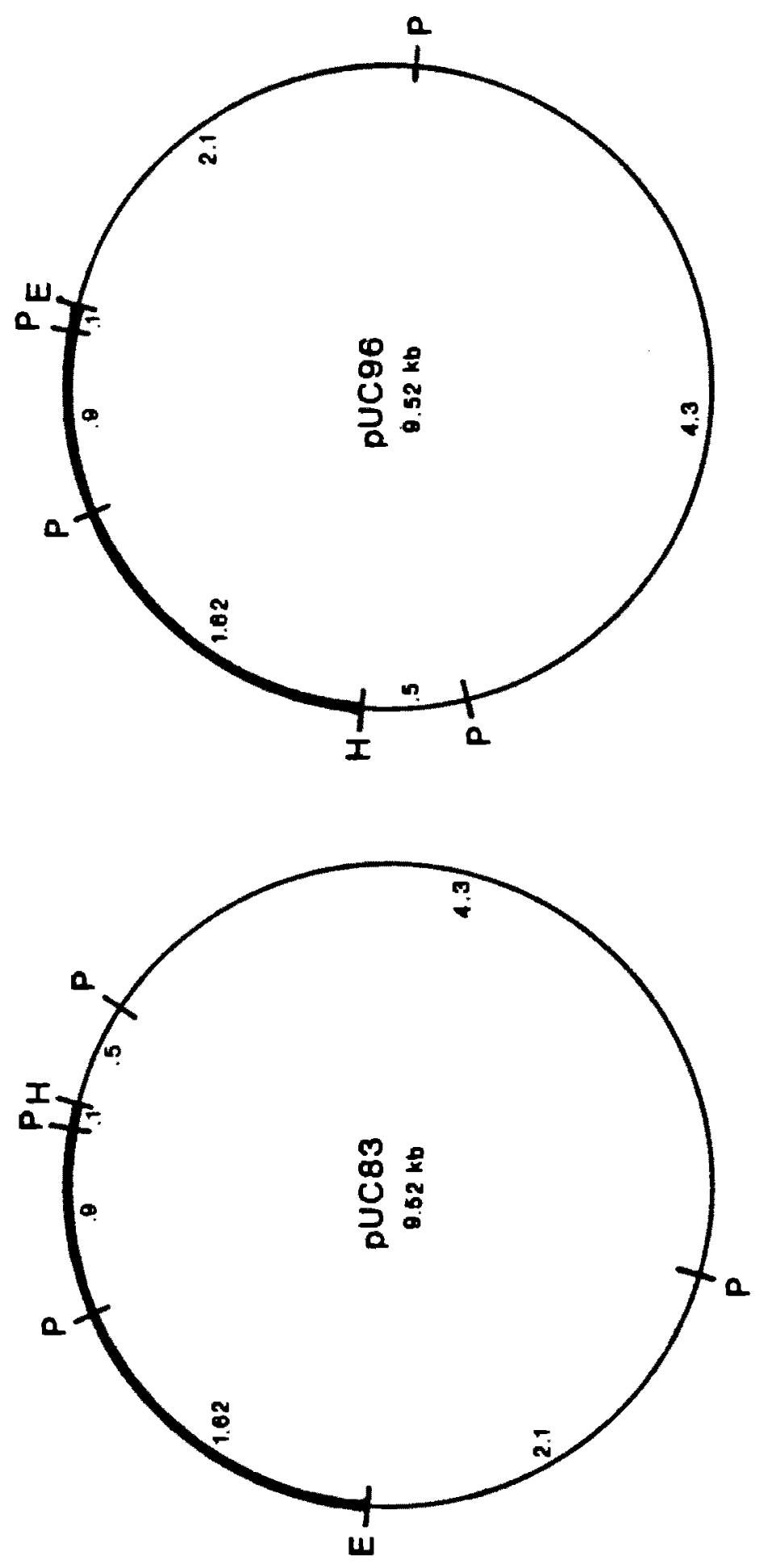
From these data the following PVu I map of the fragment was constructed:

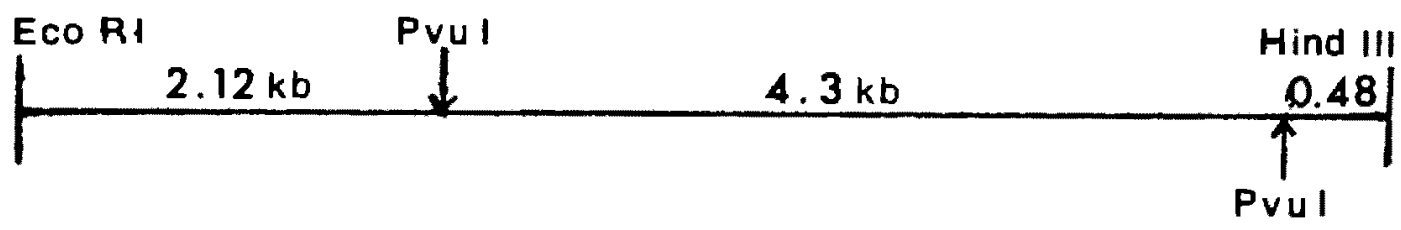

\section{Restriction Map}

The location of the Pvu I restriction sites within the R45 fragment provided a convenient starting point for constructing a restriction map of the fragment itself. Four restriction enzymes were found that cut the fragment into 2-3 smaller fragments. These were Bgl II, PVu I, Sph I and Sal I. The following enzymes have no restriction sites within the R45 fragment:

$\begin{array}{lll}\text { Pvu II } & \text { Bam HI } & \text { Sst II } \\ \text { Hind III } & \text { Cla I } & \text { Xba I } \\ \text { Eco RI } & \text { Xho I } & \text { Kpn I } \\ & & \end{array}$

The following enzymes were found to cut the fragment into an unmanageable number of smaller fragments:

$\begin{array}{ll}\text { Pst I } & \text { Hinc II } \\ \text { Hae II } & \text { Hpa I } \\ \text { Ava II } & \text { Taq I }\end{array}$


Aliquots of isolated $\mathrm{R} 45$ fragment DNA were restricted with each of the four selected enzymes, and the resulting fragment sizes estimated by electrophoresis with DNA standards. A portion of each single digest was then separately restricted with each of the remaining enzymes, resulting in a series of double digests. Each of these was analyzed on a $1.2 \%$ agarose gel. The results are given in Fig * 4 . 


\section{6}

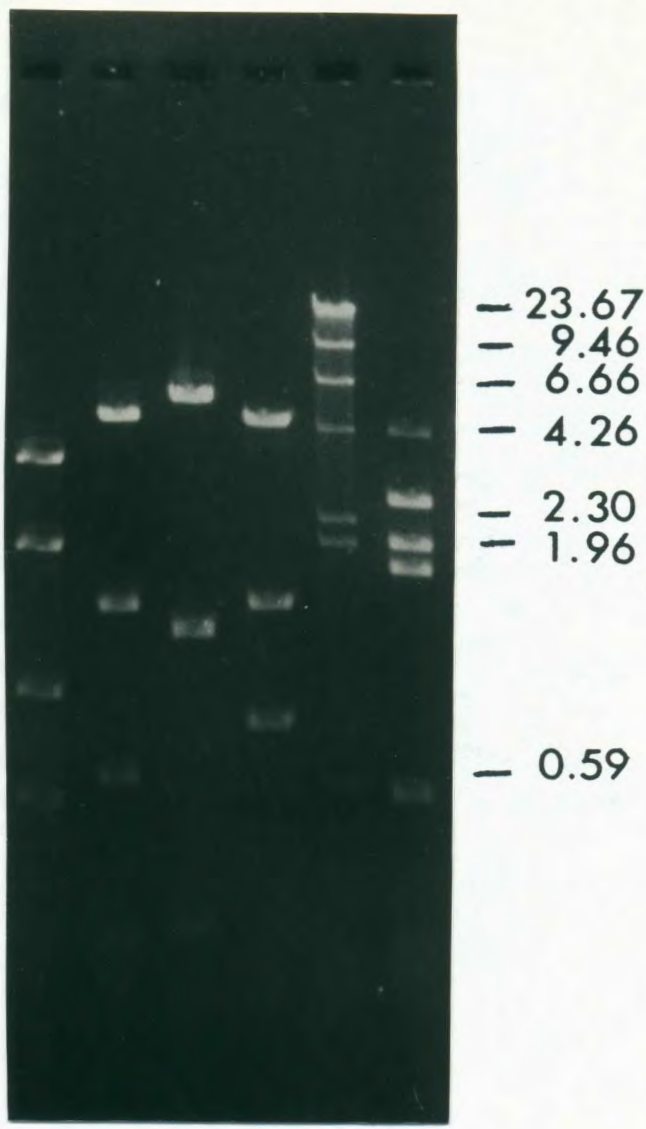

Figure 4. Double Digests of the R45 Fragment

Aliquots of R45 fragment DNA were digested with each of four restriction enzymes. Fortions of each restriction were subjected to a second digest with each of the remaining enzymes. Lane 1, Bgl II + PVu I; lane 2, Bgl II + Sal I; lane 3, Bgl II; lane 4, BgI II + Sph I; lane 5, $\lambda \mathrm{H}$; lane 6, Sph I + Pvu I. Size standards are indicated on the right in kilobases. 
The single digests resulted in fragments of the following sizes :

\begin{tabular}{llll} 
PVu I & BgI II & Sph I & $\frac{\text { Sal I }}{6.3 \mathrm{~kb}}$ \\
\hline $.6 \mathrm{~kb}$ & $5.6 \mathrm{~kb}$ & $6.1 \mathrm{~kb}$ \\
2.12 & 1.4 & 2.3 & 0.6 \\
0.48 & & 0.2 &
\end{tabular}

Fragment sizes resulting from the double digests are as follows:

\begin{tabular}{|c|c|c|c|}
\hline Bgl II+Pvu I & Bgl II+Sph I & Bgl II+Sal I & Sph I+Fvu I \\
\hline $2.12 \mathrm{~kb}$ & $4.7 \mathrm{~kb}$ & $4.75 \mathrm{~kb}$ & $2.5 \mathrm{~kb}$ \\
\hline 0.48 & 1.4 & 1.4 & 2.12 \\
\hline 0.92 & 0.8 & 0.6 & 1.8 \\
\hline 3.38 & & 0.2 & 0.5 \\
\hline
\end{tabular}

The location of the single Bgl II site can be determined when the double digest reveals that the $2.12 \mathrm{~kb}$ Pvu I fragment at the Eco RI terminus is conserved. The Bgl II site can only lie $1.4 \mathrm{~kb}$ in from the Hind III terminus. Such a location yields the double-digest fragment sizes observed. Building on this information, single and double digests resulted in the final map, as given in Fig. 5. Because the two Sal I sites do not overlap with any other sites, their locations relative to each other cannot be determined. The two Sal I sites are given dotted lines to indicate this fact. 

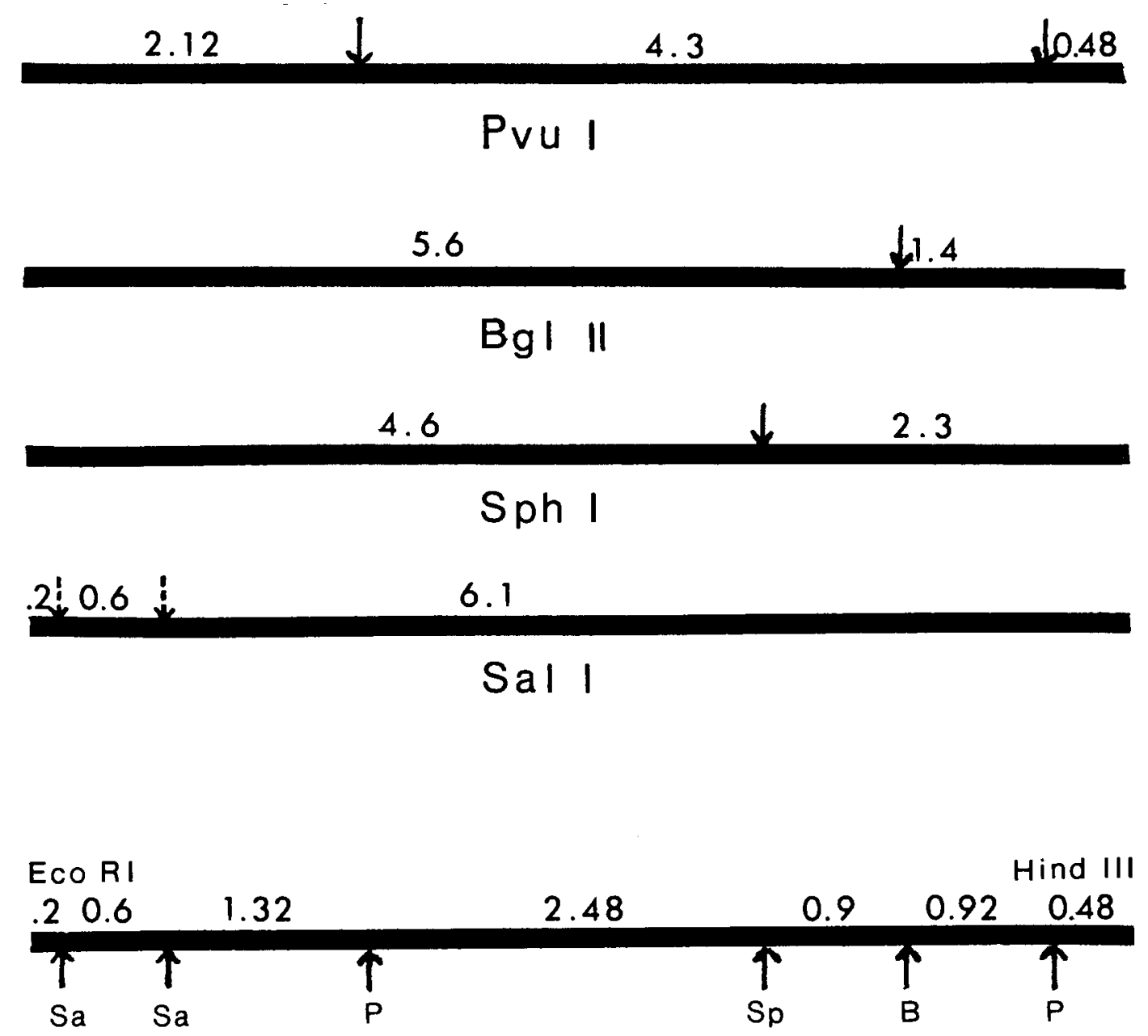

Figure 5. Single Digest Maps and Restriction Map of the R45 Fragment 
Minimal Inhibitory Concentration of Arsenite

The minimal inhibitory concentration of arsenite for each strain used, with or without recombinant plasmids, was determined by plating the strains on LA containing increasing amounts of arsenite. This allowed the selection of an arsenite concentration that would clearly distinguish between plasmid and non-plasmid-bearing strains. The results are given in Table II.

The minimal inhibitory concentration is taken to be that concentration of arsenite at which no growth is observed for a given strain. Minimal inhibitory concentrations were:

\begin{tabular}{|c|c|c|c|}
\hline $\mathrm{JM} 105$ & JM $105(p U C 84)$ & CSR 603 & CSR $603(\mathrm{pUC84})$ \\
\hline $6 \mathrm{mM}$ & $20 \mathrm{mM}$ & $4 \mathrm{mM}$ & $20 \mathrm{mM}$ \\
\hline
\end{tabular}

Although MIC's determined by this method are approximate, a sharp distinction can be seen between the resistances of plasmid and non-plasmid-bearing strains.

\section{Arsenite Resistance Induction Assays}

Since the arsenite resistance fragment has been ligated into the pUC vectors next to the lac promoter, arsenite resistance may be induced from the lac promoter using IPTG. Since resistance would be induced only in clones with the fragment in the proper orientation with regard to the promoter, it should be possible to determine in which direction -- from the Eco RI site to the Hind III 
외 0000

ก 0 ㅇำ 0 ก

게 0 일

z

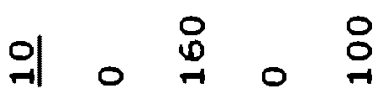

点

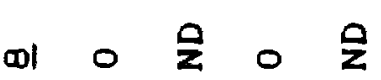

点

$\sum_{E}$

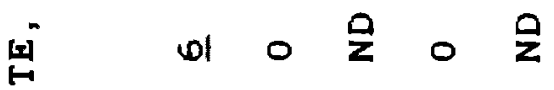

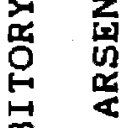

思的量

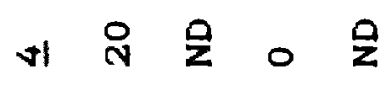

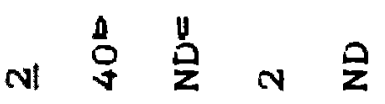

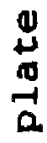

$\underset{\Sigma}{\stackrel{2}{\mid c}}$

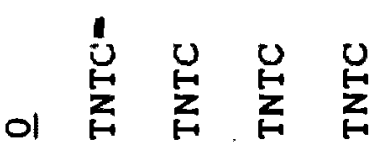

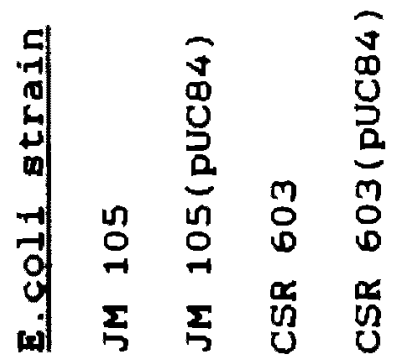

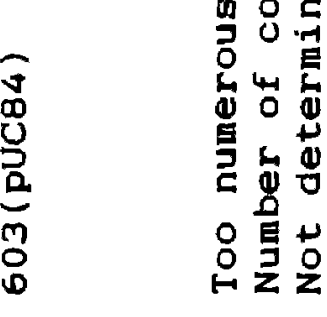

ט م 
site or vice versa -- the fragment is transcribed. When recombinant clones are pre-grown in IPTG, a lag in growth would be observed with one puc recombinant plasmid upon addition of arsenite, because transcription must be induced from the arsenite promoter. In the other orientation, resistance will have been previously induced by IPTG from the lac promoter, and no such lag would be observed. Experiments were conducted to find the optimum arsenite concentration that would consistently induce resistance and yet be subinhibitory to uninduced cultures. $1.0 \mathrm{mM}$ arsenite was selected for this purpose (Fig. 6). One strain of each orientation -- JM 105(pUC84) and JM 105 (pUC95) -- was chosen for study. 
Figure 6. Optimal Arsenite Concentration for Induction of Resistance

A: Cultures of JM 105(pUC84) were grown overnight in LB, subcultured and grown to $\log$ phase. At the time indicated by the arrow, $0.5 \mathrm{mM}, 0 ; 1.0 \mathrm{mM}, \square ; 5 \mathrm{mM}$, $\Delta$; or no arsenite, $\boldsymbol{\theta}$, were added to the culture.

B: Cultures of JM 105(pUC84) and JM 105(pUC8) were grown as above and challenged with $10 \mathrm{mM}$ arsenite at the time indicated by the arrow. JM 105 (pUC 84) was induced with $0.5 \mathrm{mM}, 0 ; 1.0 \mathrm{mM}, \square$; or no arsenite, $\Delta$. JM 105 (PUC 8) was induced with $1 \mathrm{mM}$ arsenite, 


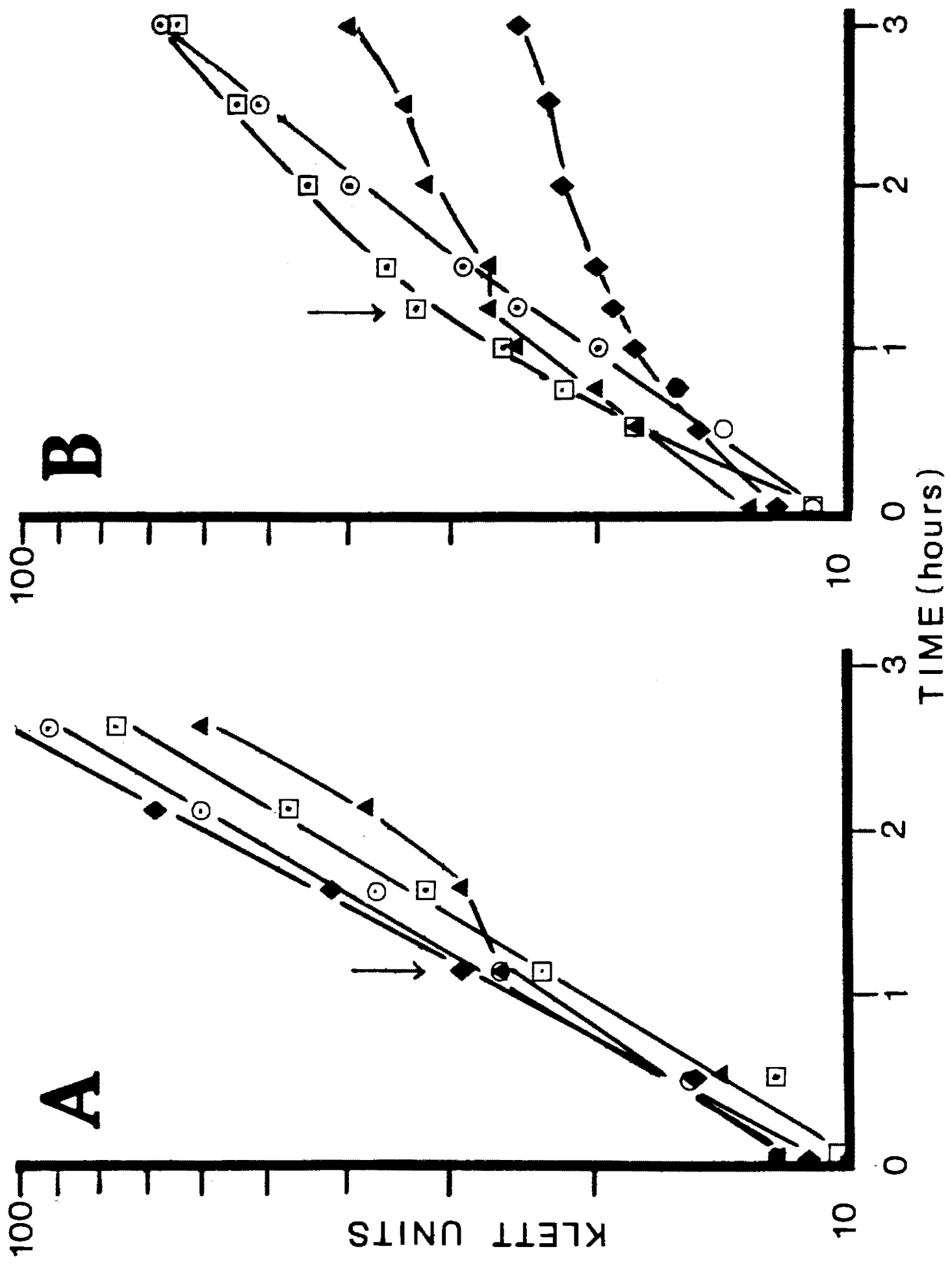


Unfortunately, IPTG did not induce resistance in either orientation under any of the conditions used. Results from a clone in the pucs orientation are shown in Fig. 7. Results in clones of the opposite orientation were identical. 
Figure 7. Induction of Resistance with IPTG

Cultures of JM 105 (pUC84) were grown overnight in LB containing the following inducers: $1 \mathrm{mM}$ arsenite, $O$; $2 \mathrm{mM}$ IPIG, $\mathbf{\square}$; none, $\Delta$. The cultures were subcultured and grown to $\log$ phase twice before being challenged with $15 \mathrm{mM}$ arsenite at the time indicated by the arrow. A culture that contained no inducer and was not challenged, $\bullet$, was included as a control. 


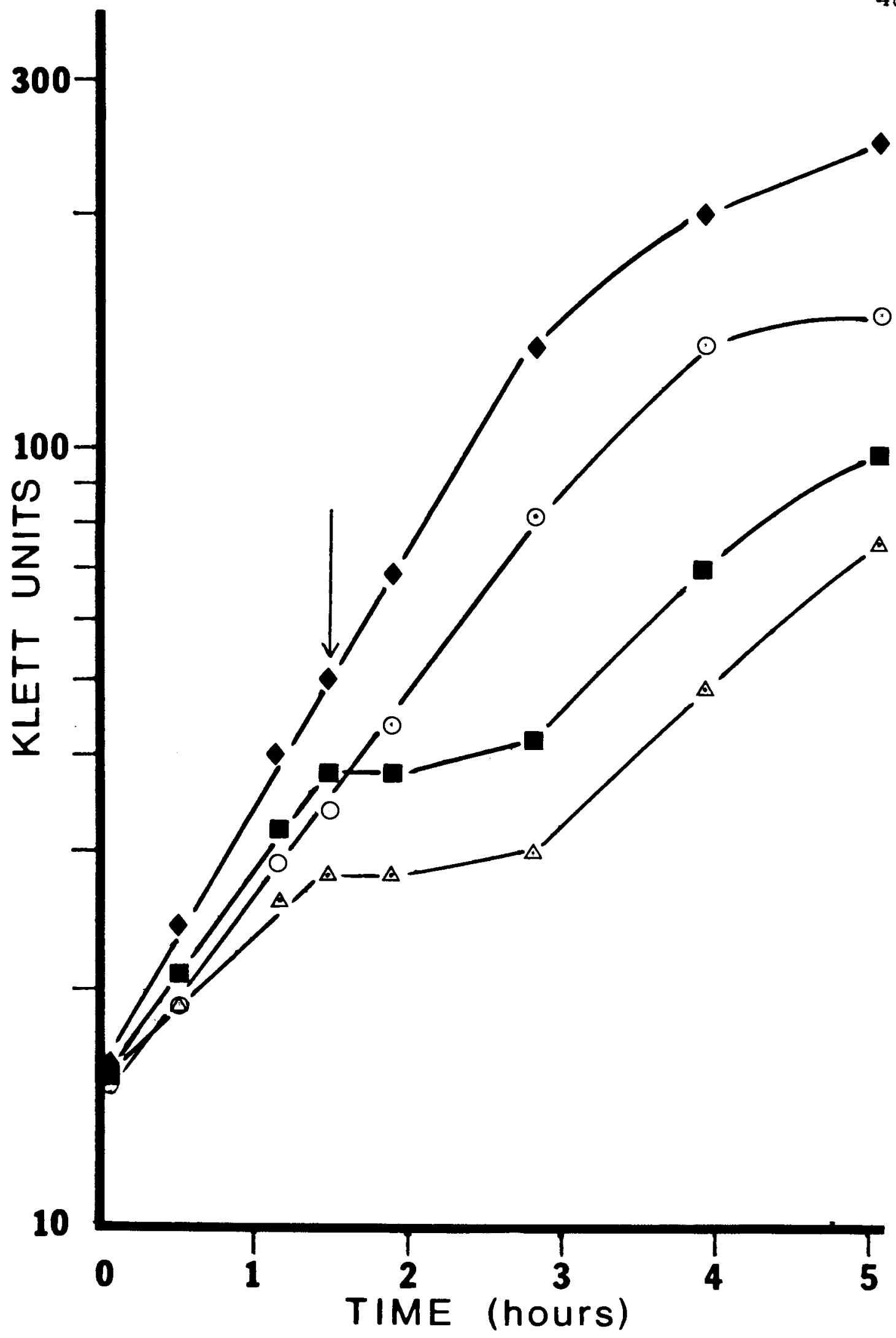




\section{Identification of Plasmid-Determined Proteins}

The plasmids pUC8, PUC84 and pUC96 were transformed into the maxicell strain E. Coli CSR 603. Uninduced and arsenite-induced strains were irradiated as previously described. This is a modification of the original maxicell procedure (31), since radioactive amino acids were not added. Due to the high copy number of the puc vectors (approximately 200 per cell) (11), it was expected that recombinant plasmid proteins would be detected without the use of radioactivity.

Because the arsenite resistance genes are inducible, proteins from cultures grown with arsenite can be analyzed for differences on a gel beside those from uninduced cultures. In order to maximize these differences, cells were induced in $10 \mathrm{mM}$ arsenite, rather than the subinhibitory $1 \mathrm{mM}$ arsenite. The host and pUC-bearing strains are not viable at this concentration, so arsenite was not included in the growth media for these strains.

In comparing induced recombinant-bearing strains against the uninduced strains, the following differences were apparent:

1. Three proteins were visible in induced lanes only, with apparent molecular weights of $62,16.5$ and 13.5 Kdal. Whereas the two smaller proteins were seen on gels stained with either silver or Coomassie blue, the 62 Kdal protein was seen only on Coomassie 
blue-stained gels (Fig. B).

2. When ampicillin was included in the medium, the mature 27 Kdal $\beta$-lactamase enzyme (37) encoded by the pUC vector was visible in all lanes, except that of the plasmid-less host strain (Fig. 9).

3. On most gels, a $36 \mathrm{Kdal}$ protein was visible in all lanes except those of the induced strains (Fig. 9). 
Figure 8. Plasmid-Determined Proteins

Various CSR 603 strains were irradiated and grown in LB without ampicillin for three hours. Cycloserine was added, and the cultures were grown eight hours before lysing. Cultures in lanes 2 and 5 also contained $10 \mathrm{mM}$ arsenite. Lanes 1, 4 and 7, protein standards; lanes 2 and 3 , 603(pUC96); lanes 5 and 6, 603 (pUC84); lane 8, 603 (pUC8); lane 9, CSR603. The sizes of plasmid-determined proteins are indicated on the left side of the figure. Protein standard sizes are indicated on the right. The gel was stained with silver, then with Coomassie blue ( 6 ). 


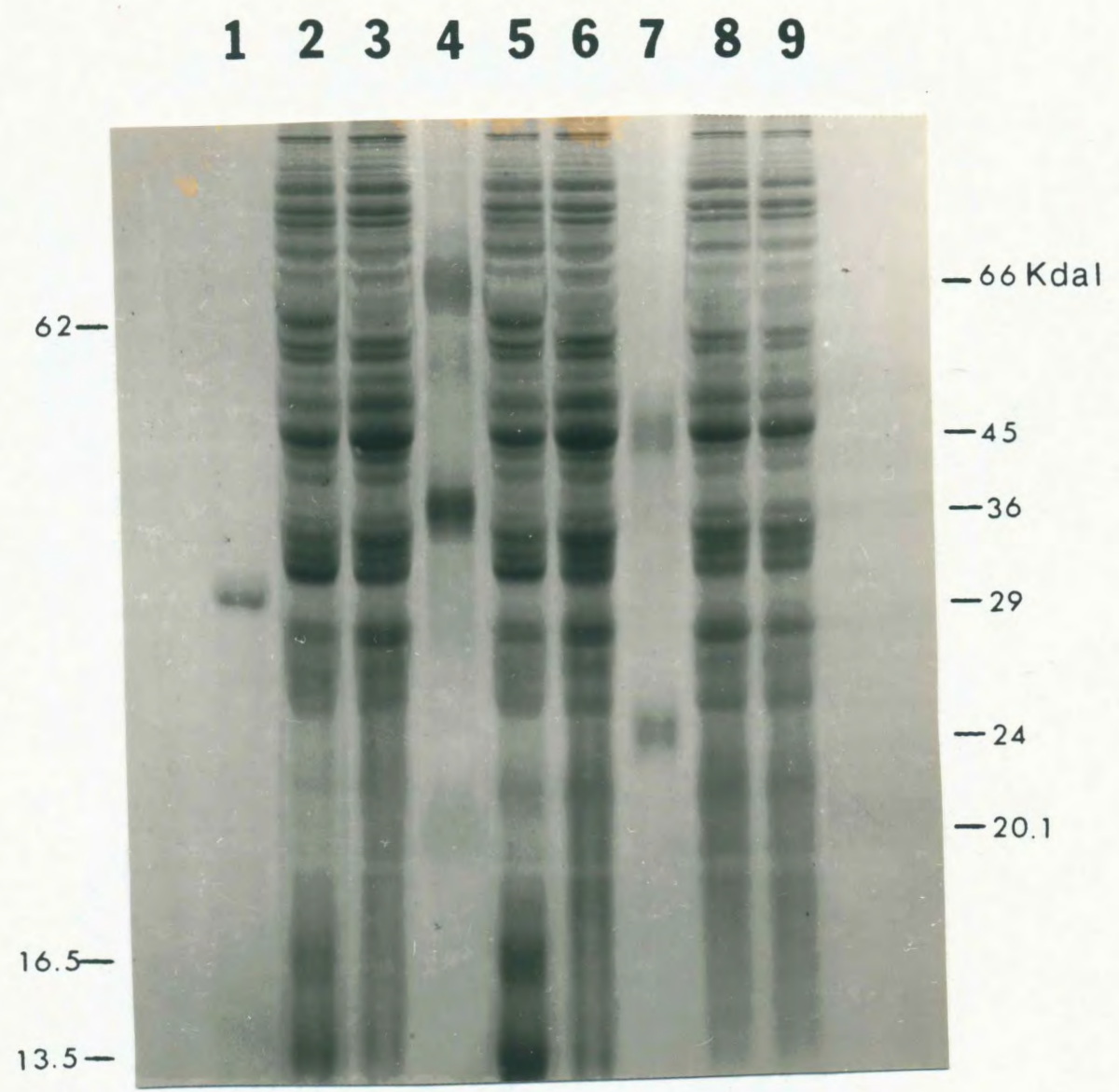


Figure 9. $\beta$-Lactamase and $36 \mathrm{Kdal}$ Protein

Various CSR 603 strains were irradiated and grown for 6 hourg in LB with $50 \mathrm{ug} / \mathrm{ml}$ ampicillin before lysing. Cycloserine was not added. Cultures in lanes 2 and 5 also contained $10 \mathrm{mM}$ arsenite. Lanes 1,4 and 7, protein standards; lanes 2 and 3, 603(puC96); lanes 5 and 6 , 603(pUC84); lane 8, 603(pUC8); lane 9,603. The $\beta$-lactamase protein ( $27 \mathrm{Kdal}$ ) encoded by the pUC vectors and the $36 \mathrm{Kdal}$ protein absent in induced strains are indicated by arrows on the left; protein standard sizes are indicated on the right. The gel was stained with Coomassie blue. 


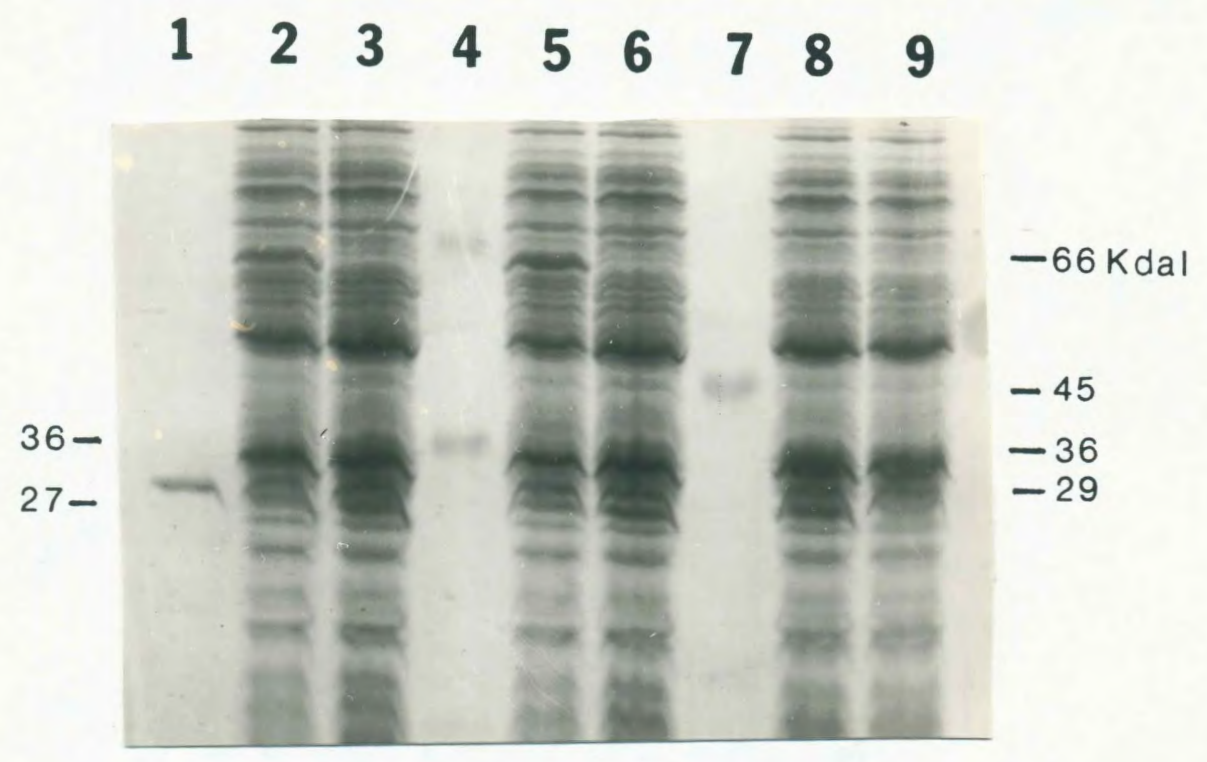




\section{DISCUSSION}

Comparison of the minimal inhibitory concentrations of arsenite for strains growing on LA shows that the MIC's of the E. coli strains JM 105 and CSR 603 are similar -- $6 \mathrm{mM}$ and $4 \mathrm{mM}$, respectively. Transformation of recombinant plasmids containing the Eco RI-Hind III fragment of R45 into these strains increases arsenite resistance by up to five-fold (the MIC was $20 \mathrm{mM}$ in both cases), confirming successful transfer of the arsenite resistance region from R45.

Strains bearing recombinant plasmids were grown in liquid medium with and without arsenite and then challenged by the addition of arsenite. Pre-induced strains continued exponential growth while uninduced strains showed a growth lag of 1-2 hours. These results indicate that the inserted fragment contains the control elements for the resistance genes.

Resistance to arsenite could not, however, be induced in either pUC84 or pUC96 using IPTG. Hence, no conclusion can be drawn regarding the direction of transcription. In another study, a $3.5 \mathrm{~kb}$ fragment of DNA containing the gene for diadenosine tetraphosphatase was cloned into the pUC vectors (17). In one orientation, addition of IPTG produced an eight-fold increase in production of this 
protein over the uninduced. In the other, no increase was observed. In a third study, however, cloning of a $2.5 \mathrm{~kb}$ region containing the gene for the activator protein of D-serine deaminase produced no such increase using IPTG in either orientation (Elizabeth McFall, personal communication).

Based on these observations, it was important to confirm that the plasmids pUC84 and pUC96 in fact contained the inserted fragment in opposite orientations. Accordingly, the plasmids were digested with the restriction enzyme PVu $I$ and, as seen in Fig. 2, this was confirmed.

A possible explanation for the inability to induce resistance from the $\underline{1}$ ac promoter is that the RNA polymerase that binds there encounters a termination signal before reaching the structural genes for arsenite resistance. Using the restriction map of the fragment (Fig. 5), one could attempt to delete the termination signal using restriction digestion.

Another possibility exists. Since induction of arsenite resistance with IPTG was attempted in media lacking arsenite, a repressor gene may be present at the asir operator. This repressor may block passage of the RNAP initiating at the lac promoter.

Digestion might also be carried out using an exonuclease, such as Bal 31. This enzyme attaches to a 
free end of DNA and continuously degrades it nonspecifically. Alternatively, Tn5 insertion mutagenesis might be used to determine the relative locations of the arsenite and arsenate genes $(3,40)$. This transposon inserts randomly into DNA and carries a unique Bam HI restriction site. Insertion into a gene results in loss of function. Bam HI digestion, followed by electrophoretic analysis and resistance assays, can reveal gene location. Promising new expression vectors based on the bacteriophage T7 might also be employed (38). This dual plasnid system is specific for the T7 promoter and ignores bacterial promoters. It also ignores bacterial RNA termination signals, circumventing the necessity to locate and delete these signals.

The modified maxicell technique used in this study revealed three polypeptides of apparent molecular weights $62,16.5$ and $13.5 \mathrm{kdal}$ present in strains bearing recombinant plasmids derived from $\mathrm{R} 45$ after induction with $10 \mathrm{mM}$ arsenite. These polypeptides were absent in cultures grown without arsenite. The $\beta$-lactamase gene in the pUC vectors is also inducible, and $\beta$-lactamase is seen only in gels from cultures containing ampicillin in the medium. This indicates that the modified procedure is capable of revealing specific plasmid-determined proteins, using appropriate media.

In addition, a polypeptide with an apparent molecular 
weight of $36 \mathrm{kdal}$ present in all cultures, including the plasmid-less host strain, is absent only from recombinant plasmid bearing cells grown in arsenite. This interesting observation was possible only in this modified maxicell procedure. The original procedure, with the addition of radioactive amino acids to identify only plasmid-encoded proteins, would not have detected it. The mechanisms responsible for this observation are unknown.

The procedures used in this study do not, however, specifically determine whether these proteins are actually encoded by the plasmid itself or induced within the cell by regulatory genes carried on the plasmids. To answer this question, the maxicell procedure described previously must be carried out with the addition of radioactive amino acids following chromosomal inactivation, to specifically label plasmid-encoded proteins.

It is known that there exists more than one mechanism for resistance to arsenite and arsenate $(27,28$ ). Much is still unknown regarding these resistances. Cel1 fractionation studies will be necessary to determine the location of the proteins within the cell. Footprinting, a technique for identifying protein binding sites on DNA by the fact that the protein protects the site from enzymatic digestion (25), can be used to ascertain whether the resistance is negatively or positively controlled. In addition, whether the resistances to arsenate and arsenite 
are due to separate efflux pumps or one pump is modified to accommodate the separate arsenic compounds remains to be determined.

In this study, the proteins determined by the arsenic resistance region of the plasmid 845 have been identified. Comparison of these proteins with those of other arsenic resistance plasmids will help illuminate the differences and similarities between their mechanisms of resistance. In addition, a restriction map of the region has been prepared which can be used to further localize the arsenic resistance genes and study their organization and regulation. 


\section{REFERENCES}

1. Birnboim, H.C., and J. Doly. 1979. A Rapid Alkaline Extraction Procedure for Screening Recombinant Plasmid DNA. Nuc; Acids. Res. 7:1513.

2. Casse, Francine, C. Boucher, J.S. Julliot, M. Michel and J. Denarie. 1979. Identification and Characterization of Large Plasmids in Rhizobium meliloti Using Agarose Gel Electrophoresis. J. Gen. Microbiol. 113:229

3. Chen, Chih-Ming, Harry L.T. Mobley and Barry P. Rosen. 1985. Separate Resistances to Arsenate and Arsenite (Antimonate) Encoded by the Arsenical Resistance Operon of R Factor $k 773$.

J. Bacteriol. 161:758.

4. Davis, Ronald $W$., David Botstein and John R. Roth. 1980. Advanced Bacterial Genetics. Cold Spring Harbor Laboratory.

5. Dretzen, G., M. Bellard, P. Sassone-Corsi and P. Chambon. 1981. A Reliable Method for the Recovery of DNA Fragments from Agarose and Acrylamide Gels. Anal. Biochem. $112: 295$.

6. Dzandu, James K., Mercy E. Deh, Denise L. Barratt and Gary E. Wise. 1984. Detection of Erthrocyte Membrane Proteins, Sialoglyco-proteins, and Lipids in the same Polyacrylamide Gel Using a Double-Staining Technique. Proc. Nat. Acad. Sci. 81:1733

7. Ferguson, John F. And Jerome Gavis. 1972. A Review of the Arsenic Cycle in Natural Waters. Water Res. $6: 1259$.

8. Ferrazza, David and Stuart B. Levy. 1980. Biochemical and Immunological Characterization of an $R$ Plasmid-Encoded Protein with Properties Resembling Those of Major Cellular Outer Membrane Proteins. J. Bacteriol. 144:149 
9. Fong, Kenneth, Frank Lee and Richard Bockrath. 1980. Effects of Sodium Arsenite on Single-strand DNA Break Formation and Post-Replication Repair in E. coli Following UV Irradiation. Mutat. Res. 70:151.

10. Hedges, R.W. and S. Baumberg. 1973. Resistance to Arsenic Compounds Conferred by a Plasmid Transmissible Between Strains of Escherichia coli. J. Bacteriol. $115: 459$.

11. Heincz, Maria C., Susan M. Bornstein and Elizabeth McFall. 1984. Purification and Characterization of d-Serine Deaminase Activator Protein. J. Bacteriol. $160: 42$.

12. Laemmli, U.K. 1970. Cleavage of Structural Proteins During the Assembly of the Head of Bacteriophage T4. Nature 227:680.

13. Lawn, A.M., Elinor Meynell, G.G. Meynell, Naomi Datta. 1967. Sex Pili and the Classification of Sex Factors in the Enterobacteriaceae. Nature 216:343.

14. Mandel, M. and A. Higa. 1970. Calcium-Dependent Bacteriophage DNA Infection. J. Mol. Biol. 53:159.

15. Maniatis, T., E.F. Fritsch and J. Sambrook. 1982 . Moleculuar Cloning: A Laboratory Manual. Cold Spring Harbor Laboratory.

16. McDonell, Michael W., Martha N. Simon and F. William Studier. 1977. Analysis of Restriction Fragments of T7 DNA and Determination of Molecular Weights by Electrophoresis in Neutral and Alkaline Gels. J. Mol. Biol. $110: 119$

17. Mechulam, Yves, Michel Fromant, Patrice Mellot, Pierre Plateau, Sylvie Blanchin-Roland, Guy Fayat and Sylvain Blanquet. 1985. Molecular Cloning of the Escherichia coli Gene for Diadenosine 5', 5" '-P1, P-Tetraphosphate Pyrophosphohydrolase. J. Bacteriol. 164:63.

18. Mendez, Beatriz, Chikanori Tachibana and Stuart B. Levy. 1980. Heterogeneity of Tetracycline Resistance Determinants. Plasmid 3:99.

19. Messing, Joachim. 1983. New M13 Vectors for Cloning. In Methods in Enzymology, Vol. 101. Academic Press. 
20. Metzler, David E. 1977. Biochemistry. Academic Press.

21. Miller, J.M. ed. 1972. Experiments in Molecular Genetics. Cold Spring Harbor Laboratory, New York.

22. Mobley, Harry L.T., Simon Silver, F.D. Porter and Barry P. Rosen. 1984. Homology Among Arsenate Resistance Determinants of R Factors in Escherichia coli. Antimicrob. Agents Chemother. 25:157.

23. Mobley, Harry L.T. and Barry P. Rosen. 1982.

Energetics of Plasmid-Mediated Arsenate Resistance in Escherichia coli. Proc. Natl. Acad. Sci. 79:6119.

24. Myers, John W., W. Herman Taylor and Mary L. Taylor. 1983. Localization of Genes Coding for Arsenate and Arsenite Resistance on the Plasmid, R45. Abstr. Oregon Acad. Sci.

25. Nick, Harry and Walter Gilbert. 1985. Detection in vivo of Protein-DNA Interactions Within the lac Operon of Escherichia coli. Nature 313:795.

26. Novick, Rochard F. and Christine Roth. 1968. Plasmid-Linked Resistance to Inorganic Salts in Staphylacoccus aureus. J. Bacteriol. 95:1335.

27. Osborne, F.H. and H.L. Ehrlich. 1976. Oxidation of Arsenite by a Soil Isolate of Alcaligenes. J. Appl. Bact. $41: 295$.

28. Phillips, Shirley E. and Mary L. Taylor. 1976. oxidation of Arsenite to Arsenate by Alcaligenes faecalis. Appl. Environ. Microbiol. 32:392.

29. Pugsley, Anthony P. and Carl A. Schnaitmen. 1978. Identification of Three Genes Controling Production of New Outer Membrane Pore Proteins in Escherichia coli K-12. J. Bacteriol. 135:1118.

30. Rosen, Barry P. and Miguel G. Borbolla. 1984. A Plasmid-Encoded Arsenite Pump Produces Arsenite Resistance in Escherichia coli. Biochem. Biophys. Res. Commun. 124:760.

31. Sancar, Aziz, Adelle M. Hack and W. Dean Rupp. 1979. Simple Method for Identification of Plasmid-Coded Proteins. J. Bacteriol. 137:692. 
32. Schleif, Robert F. And Pieter C. Wensink. 1981. Practical Methods in Molecular Biology. Springer-Verlag.

33. Silver, S., K. Budd, K.M. Leahy, W.V. Shaw, D. Hammond, R.P. Novick, G.R. Willsky, M.H. Malamy and H. Rosenberg. 1981. Inducible Plasmid-Determined Resistance to Arsenate, Arsenite and Antimony(III) in Escherichia coli and Staphycoloccus aureus. J. Bacteriol. 146:983.

34. Smiley, D.G. 1981. A Genetic and Physiological Study of an Arsenite Resistant, Uncoupled Mutant of Escherichia coli. Portland State University. M.S. Thesis.

35. Smith, H. Williams, Z, Parsell and P. Green. 1978. Thermosensitive Antibiotic Resistance Plasmids in Enterobacteria. J. Gen. Microbiol. 109:37.

36. Sunderman, F. William, Jr. 1976. A Review of the Carcinogenicities of Nickel, Chromium and Arsenic Compounds in Man and Animals. Prev. Med. 5:279.

37. Sutcliffe, J. Gregor. 1978. Nucleotide Sequence of the Ampicillin Resistance Gene of Escherichia coli Plasmid pBR322. Proc. Nat. Acad. Sci. 75:3737.

38. Tabor, Stanley and Charles C. Richardson. 1985. A Bacteriophage T7 RNA Folymerase/Promoter System for Controlled Exclusive Expression of Specific Genes. Proc. Natl. Acad. Sci. 82:1074

39. Thomas, Christopher M., Richard Meyer and Donald R. Helinski. 1980. Regions of Broad-Host-Range Flasmid RK2 Which are Essential for Replication and Maintenance. J. Bacteriol. 141:213.

40. Trezona, Thomas. 1981. Plasmid-Mediated Resistance to Arsenite and Arsenate in Escherichia coli. Portland State University. M.S. Thesis.

41. Vieira, Jeffrey and Joachim Messing. 1982. The pUC Plasmids, an M13mp7-Derived System for Insertion Mutagenesis and Sequencing with Synthetic Universal Primers. Gene 19:259.

42. Willsky, Gail R. And Michael H. Malamy. 1980. Effect of Arsenate on Inorganic Phosphate Transport in Escherichia coli. J. Bacteriol. 144:366. 
43. Wray, Wayne, T. Boulikas, Virginia P. Wray and Ronald Hancock. 1981. Silver Staining of Proteins in Polyacrylamide Gels. Anal. Biochem. 118:197.

44. Yanisch-Perron, Celeste, Jeffrey Vieira and Joachim Messing. 1985. Improved M13 Phage Cloning Vectors and Host Strains: Nucleotide Sequences of the M13mp18 and pUC19 Vectors. Gene 33:103. 